\title{
Sustainable management of chickpea pod borer. A review
}

\author{
Somanagouda B. Patil ${ }^{1}$ Aakash Goyal ${ }^{1}$ - Satish S. Chitgupekar ${ }^{2}$ - Shiv Kumar ${ }^{1}$. \\ Mustapha El-Bouhssini ${ }^{1}$
}

Accepted: 26 April 2017 / Published online: 2 June 2017

(C) INRA and Springer-Verlag France 2017

\begin{abstract}
The pod borer [Helicoverpa armigera Hubner (Lepidoptera: Noctuidae)] is responsible for causing up to $90 \%$ damage in chickpea due to its regular occurrence from the vegetative growth to the pod formation stage. In order to manage this problem, growers are tempted to increase the amounts of pesticides, but indiscriminate or injudicious use of pesticides has resulted in residues in the food chain, pesticide resistance, and pest resurgence, in addition to causing harm to non-targeted beneficial organisms and the environment. Here, we reviewed the sustainable approaches to reduce the incidence of pod borer and achieve sustainability in chickpea production systems through the adoption of an integrated approach involving host plant resistance, good agronomic practices, and judicious use of chemical and biological methods. We found that the following major points have been reported to reduce the survival and damage of pod borer: (1) use of resistant varieties (the cheapest and the best method of pod borer management); (2) implementing a number of good agronomic practices, such as early sowing with optimum planting density and fertilizer levels, including inter/trap crops (coriander, mustard, linseed, sunflower, sorghum, and marigold) and installing animated bird perches and T-perches at $2 \mathrm{~m}$ distance of predatory zones; and (3) monitoring pod borer through pheromone traps (which is also necessary to understand the major factors influencing pest population and to make the pest control program more effective). Integrating all of these approaches with biological control has shown some encouraging results for sustainable pod borer management and has resulted in high
\end{abstract}

Aakash Goyal

akgroyal@gmail.com

1 International Center for Agricultural Research in the Dry Area (ICARDA), B.P. 6299, Rabat, Morocco

2 University of Agricultural Sciences, Krishinagar, Dharwad, Karnataka 580 005, India chickpea yields. This review highlights examples of successful management approaches from past studies that were implemented in experimental and farmers' fields. These approaches can be explored as reproducible practices for managing the pest in locations with similar $H$. armigera concerns. We conclude that an integrated approach is most effective for long-term sustainable management programs.

Keywords Pod borer · Helicoverpa armigera . Chickpea . Good agronomic practices $\cdot$ Breeding for resistance $\cdot$ IPM . Sustainable management

\section{Contents}

1. Introduction

2. Biology of pod borer

3. Nature of damage

4. Management options

4.1. Pod characteristics and varietal resistance to H. armigera

4.2. Breeding of resistant varieties

4.3. Agronomic manipulations

4.3.1. Sowing time

4.3.2. Plant density/planting geometry

4.3.3. Nutrient management

4.3.4. Inter/mixed cropping

4.3.5. Trap crops

4.3.6. Bird perches

4.4. Monitoring of Helicoverpa through pheromone traps

4.5. Biological control

4.5.1. Plant and animal-based extracts

4.5.2. Bacteria-based insecticides

4.5.3. Virus-based insecticides

4.6. Integrated management practices

5. Conclusion

References 


\section{Introduction}

Chickpea (Cicer arietinum L.) is a legume crop of the Fabaceae family, Faboideae subfamily. It is also known as gram or Bengal gram, garbanzo, or garbanzo bean, and is sometimes known as Egyptian pea, or chana. Its seeds are high in protein. There are two different kinds of chickpea, Desi and Kabuli, based on the size, shape, and color of the seeds. Nutritionally, it contains $24 \%$ protein, $59.6 \%$ carbohydrates, and $3.2 \%$ minerals (Bakr et al. 2004). It has the ability to fix atmospheric nitrogen and can also tolerate high temperatures during and after flowering (Cumming and Jenkins 2011). It is one of the earliest cultivated legumes: 7500 -year-old remains have been found in the Middle East (Bell 2014).

Globally, chickpea is grown over an area of 13.54 million hectares with a production of 13.10 million tons and productivity of $968 \mathrm{~kg} \mathrm{ha}^{-1}$. The major chickpea-producing countries (Fig. 1) are India (67.41\%), Australia (6.21\%), Pakistan (5.73\%), Turkey (3.86\%), and Myanmar (3.74\%) (FAOSTAT 2015).

Eleven different insect-pests have been reported as the main damaging pests of the chickpea crop (Rahman et al. 1982). Among these, the pod borer, Helicoverpa armigera (Hubner), is considered to be the most serious insect-pest (Anwar and Shafique 1993), causing on average 30-40\% damage to pods (Luckmann and Metcalf 1975; Saleem and Younis 1982; Rahman 1990; Hashmi 1994), which may increase to 80-90\% in conducive environments (Sehgal and Ujagir 1990; Sachan and Katti 1994). The chickpea's economic threshold is one pod borer larva per meter row length (Sharma 1985; Zahid et al. 2008). The past decade has seen three major pod borer outbreaks, causing 10-80\% yield losses due to pod damage (Yelshetty 1999). Monetary losses result from the direct reduction in crop yield and the cost of monitoring and controlling insect-pests,

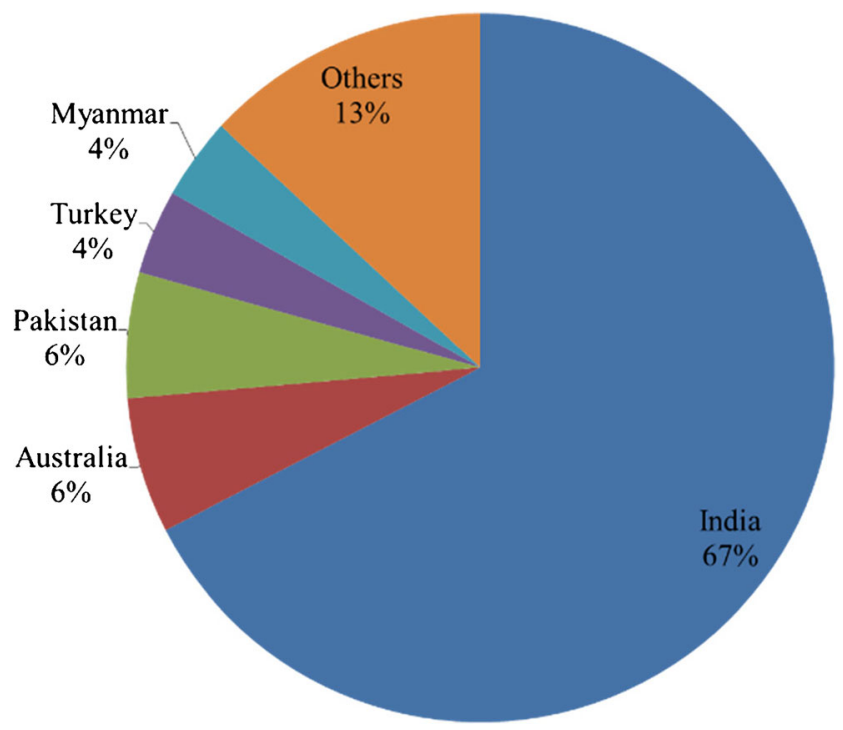

Fig. 1 Major chickpea-producing countries particularly the cost of insecticides. The extent of chickpea losses has been estimated at over US\$328 million in the semi-arid tropics (ICRISAT 1992). Worldwide, losses due to Helicoverpa in cotton, legumes, vegetables, cereals, etc., exceed US\$2 billion and the cost of insecticides used to control these pests is over US\$1 billion annually (Reed and Pawar 1982).

Among the different species, $H$. armigera and $H$. punctigera (Lepidoptera: Noctuidae) are the major pod borers in chickpea. $H$. armigera is widely distributed in Asia, Africa, the Mediterranean region, and Oceania (EPPO 2006), while $H$. punctigera is restricted to southern regions of Australia. Additionally, outbreaks of $H$. armigera were reported in Hungary, Italy, Romania, Slovakia, Spain, Sweden, Switzerland, and the UK. The global distribution of this species is shown in Fig. 2, adapted from CABI (2013). Given the pest status in Europe, H. armigera is established as a widespread pest in Bulgaria, Greece, Portugal, Romania, and Spain, with restricted distribution in Cyprus, France, Hungary, and Italy. Substantial yield losses due to this pest have been reported across South Asia. For example, 10-85\% yield losses in chickpea have been documented in India (Reed 1983; Ahmed 1984; Lal et al. 1985a; Das 1987; Qadeer and Singh 1989; Yadava and Lal 1997). In Bangladesh and Nepal, pod borer damage in unprotected chickpea fields has been in the range of 5-15\% (Musa 2000; Pande and Narayana Rao 2000). In northern Pakistan, up to $90 \%$ pod damage due to $H$. armigera has been recorded in unprotected chickpea fields (Ahmed et al. 1986; Anonymous 1987). Crop rotation with a similar host crop, introduction of new varieties, land reclamation, pest migration, and the use of irrigation and fertilizer have contributed to the increase populations of polyphagous insect-pests such as $H$. armigera (Rivnay 1962; Talhouk 1969; Elmosa 1981; Hariri 1981; White 1987). Irrigation schemes create new habitats that promote the migratory process in some insect species, the populations of which usually build up and migrate to areas that were otherwise beyond their reach (Bhatnagar 1987). Large-scale cultivation of cotton and pigeon pea (the preferred hosts of $H$. armigera) in south and central India has further aggravated the general pest situation due to population shifts of the pest from one host to another. In Pakistan, during the chickpea season of 2001-2002, an outbreak of $H$. armigera was reported by farmers growing chickpea near cotton areas (Anonymous 2002).

\section{Biology of pod borer}

Life cycles of $H$. armigera take about 30-34 days with an average temperature of $28^{\circ} \mathrm{C}$ from egg to adult (Zalucki et al. 1986). Below are details on the characteristics of eggs, larvae, pupae, and adults, and the life cycles of $H$. armigera are given in Fig. 3 (CABI 2013). The oviposition period lasts for 5 to 24 days, and a female may lay up to 3000 eggs (mainly at night) on leaves, flowers, and pods. Eggs are laid singly on leaves, flowers, and 


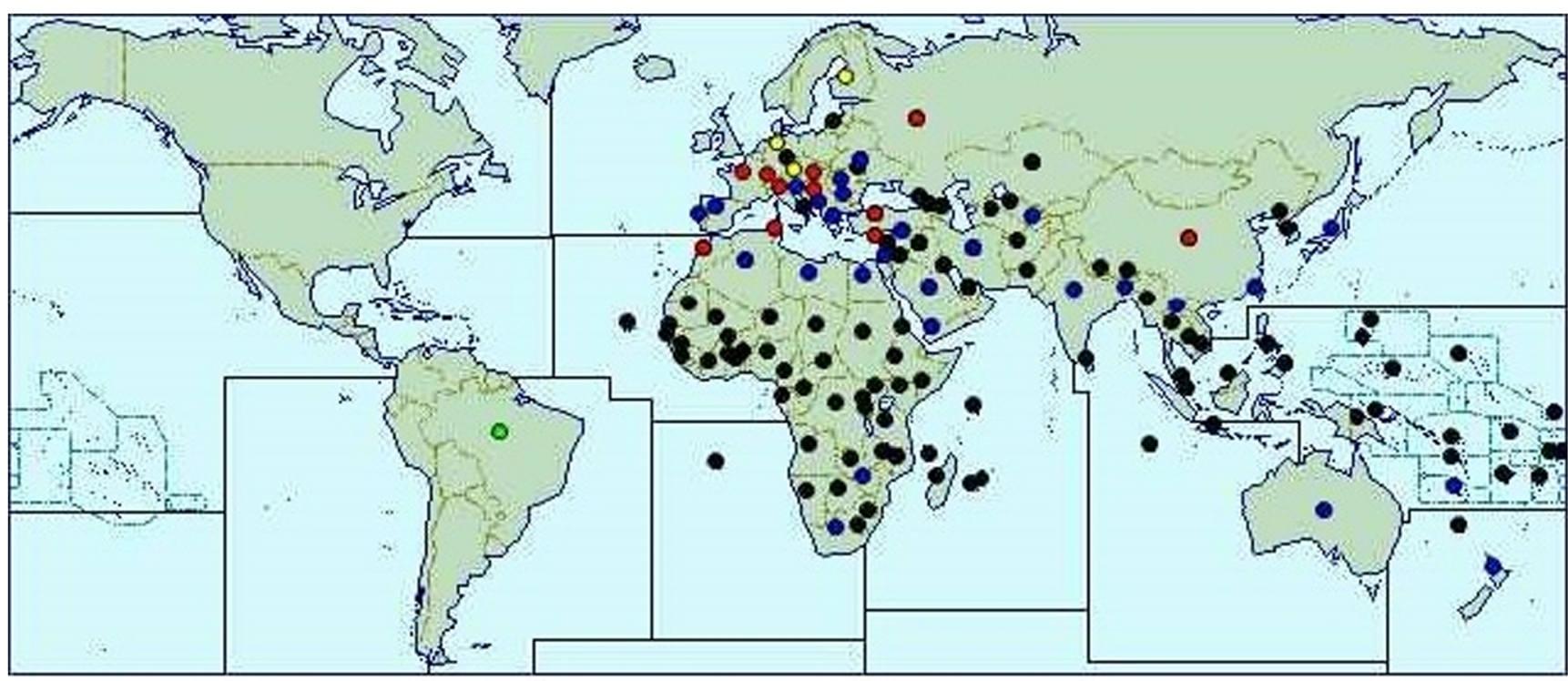

\section{=Present, no further details $\quad 0$ = Widespread $\quad 0=$ Localised \\ $\mathrm{O}=$ Confined and subject to quarantine $\quad \mathrm{O}=$ Occasional or few reports \\ $O=$ Evidence of pathogen $\quad O=$ Last reported... $\quad O=$ Presence unconfirmed \\ $O=$ See regional map for distribution within the country}

Fig. 2 Distribution map of Helicoverpa armigera (image courtesy of CABI, extracted from http://www.cabi.org/cpc/?compid=1\&dsid= 26757\&loadmodule $=$ datasheet $\&$ page $=868 \&$ site $=161$ )

young pods. The egg incubation period depends on temperature and varies between 2 and 5 days (usually 3 days). The duration of larval development depends not only on the temperature but also on the nature and quality of the host plant. It varies between 15.2 days on maize and 23.8 days on tomato. The number of larval instars varies from 5 to 7 , with 6 being most common (Ali et al. 2009). The larvae pupate is in the soil. The pre-pupal period lasts for 1 to 4 days. The larvae spin a loose web of silk before pupation. In non-diapausing pupae, the pupal period ranges from about 6 days at $35^{\circ} \mathrm{C}$ to over 30 days at $15^{\circ} \mathrm{C}$ (Ali et al. 2009). The diapausing period for pupae can last several months. Palecolored adults are produced from pupae exposed to temperatures exceeding $30^{\circ} \mathrm{C}$. Female moths generally live longer than males. In the laboratory, longevity varies from 1 to 23 days for males and 5 to 28 days for females (Pearson 1958) (Figure 3).

The pod borer exhibits a facultative diapause, which allows it to survive adverse weather conditions in both winter and summer seasons (Hackett and Gatehouse 1982; CABI 2007) Crop Protection Compendium, 2007 Edition. (C) CAB International Publishing, Wallingford. The winter diapause is induced by exposure of the larvae to short photoperiods and low temperatures. In China and India, pod borer populations are composed of tropical, sub-tropical, and temperate ecotypes. In subtropical Australia, the pod borer undergoes diapause during the winter, when temperatures are low. High temperatures can also induce diapause. It enters a true summer diapause when the larvae are exposed to very high temperatures $\left(43{ }^{\circ} \mathrm{C}\right.$ for $8 \mathrm{~h}$ daily), although the proportion of females entering diapause is nearly half compared with that of males. At these temperatures, non-diapausing males are sterile.

\section{Nature of damage}

The 1st, 2nd, and 3rd instar larvae initially feed on the foliage (young leaves) of chickpeas and a few other legumes, but mostly on the flowers and flower buds of cotton, pigeon pea, etc. Larvae shift from foliar feeders to developing seeds and fruits as larval instar development progresses (Reed and Pawar 1982). The young chickpea seedlings may be destroyed completely, particularly under tropical climates in southern India. Larger larvae bore into pods/bolls and consume the developing seeds inside the pod. In Australia, where the climate is cooler, the pod borer populations build up in spring, attacking chickpea in late spring before moving on to summer crops growing in the sub-tropical regions.

The most important host crops of $H$. armigera are tomato, cotton, pigeon pea, chickpea, sorghum, and cowpea. Other hosts include dianthus, pelargonium, chrysanthemum, groundnut, okra, peas, field beans, soybeans, lucerne, Phaseolus spp., other Leguminosae, tobacco, potatoes, maize, flax, a number of fruits (Prunus, Citrus), forest trees, and a range of vegetable and flower crops (Chandra and Rai 1974; 
Fig. 3 Life cycle of the pod borer (image courtesy of Varela AM, extracted from http:// helicoverpaaspests.weebly.com/ life-cycles.html)

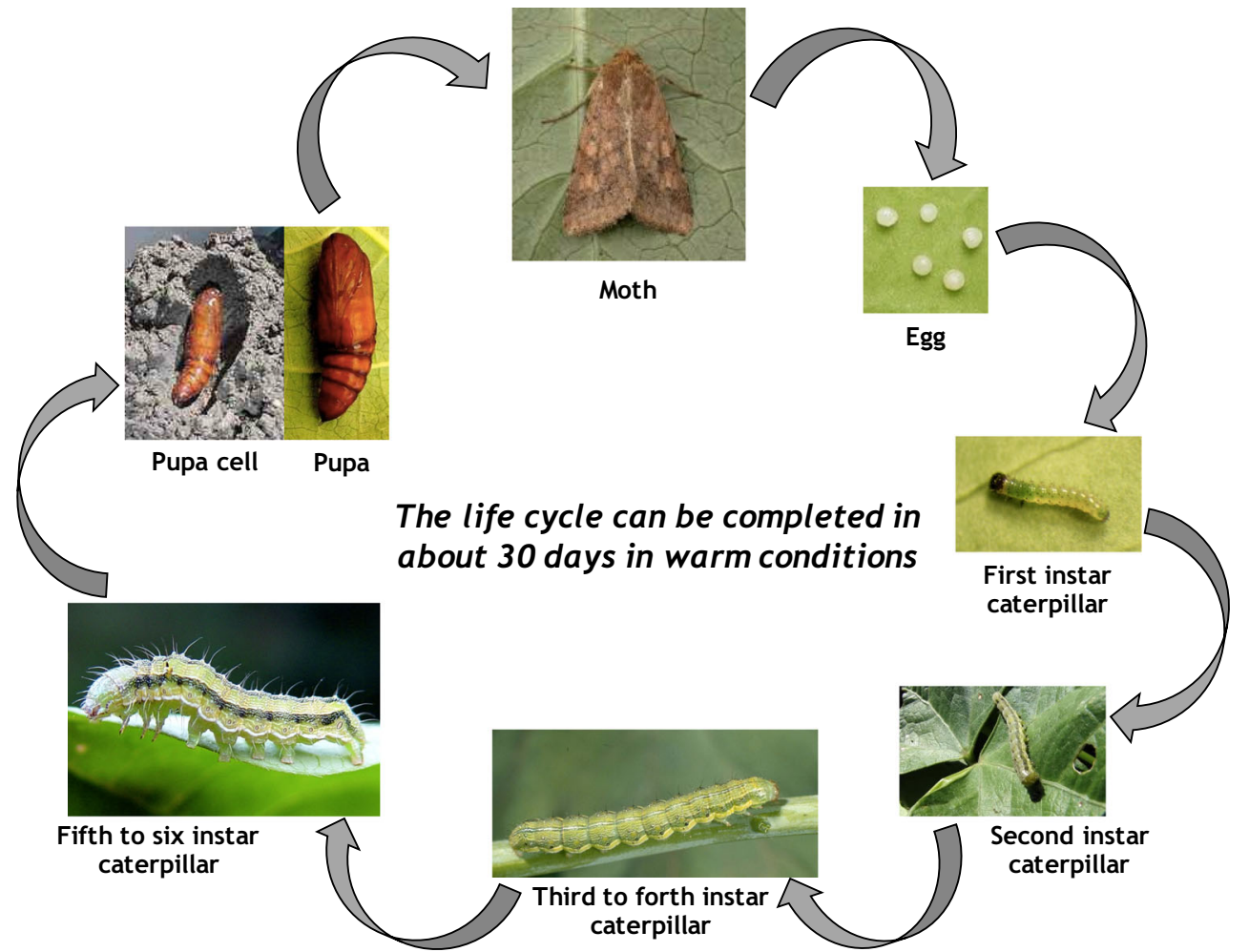

Gahukar 2002; Multani and Sohi 2002; Kakimoto et al. 2003; CABI 2006). The pod borer attacks crops from seedling to maturity, damaging all parts of the plant (leaves, flowers, and pods). Initially, the larvae feed on the leaves and tender twigs of the chickpea plant, and later, when the pods are formed, the larvae bore into the pods and feed, resulting in low yield.

The young pod borer larvae (1st, 2nd, and 3rd instar) occasionally enter the pod and feed upon the developing chickpea grains, but more often they feed from outside the pod with only the anterior part of its body in the pod (Saxena 1978; Singh and Singh 1987). A detailed study done by Patel et al. (2010) indicated that pod borer caused maximum entry holes at the basal region of chickpea pods irrespective of the genotypes.

\section{Management approaches}

Detailed knowledge of the life cycle of an insect-pest, and how it is affected by the environment, provides a scope for adjusting the agronomic practices of a crop so as to lessen the effect of the pest. Farmers mainly rely on insecticides for pod borer management. Insecticides are costly, and their indiscriminate use has induced pesticide resistance and caused environmental pollution (Phokela et al. 1990; Armes et al. 1996; Tabashnik et al. 2009; Cothran et al. 2013; Singh and Mandal 2013). In view of the above, it is necessary to manage the pest in a more ecofriendly manner. Efforts have been made towards exploiting the sustainable pest management options such as varietal resistance, agronomic practices, biological control measures, and integrated approaches.

\subsection{Pod characteristics and varietal resistance to $H$. armigera}

Many morphological characteristics which contribute to antixenosis have been used to breed pod borer-resistant varieties. Morphological traits such as pod trichome length and density, pod wall thickness, pod length, breadth and area, and number of pods per plant showed influence on pod borer resistance in chickpea (Ujagir and Khere 1987; Hossain et al. 2008a). Trichomes and trichome exudates on plant surfaces play an important role in the host selection process of insect herbivores. The types of trichomes and their orientation, density, and length have been correlated with reduced insect damage in several crops (Jeffree 1986; David and Easwaramoorthy 1988; Peter et al. 1995). The relationship between pod wall thickness and pod borer damage indicated a negative correlation, which suggested that the chickpea genotypes with a thicker pod wall received less pod borer damage. The pod length, breadth, and area of respective genotypes showed a significant effect on the resistance mechanism against pod borer damage. It showed a negative correlation between the pod length, breadth and area, and pod borer 
damage. However, a positive correlation was found between pods per plant and pod borer damage.

\subsection{Breeding resistant varieties}

Developing resistant varieties provides a foundation on which to build an integrated control system against any insect-pest. The reduction in pest number through the use of resistant plants is constant and cumulative and incurs almost no additional cost to the farmers. Therefore, the breeding goal should be to identify, characterize, and utilize a genetic mechanism that confers a durable resistance to pod borer (i.e., multiple factor resistance). Developing improved cultivars with resistance to pod borer is simple if a good source of resistance is available and an efficient and practical screening procedure exists that can provide good selection pressure. Depending on the crop's reproductive system, standard selection procedures can be adopted. Pedigree, bulk, and mass selection approaches have been successfully employed to develop tolerant or resistant cultivars in chickpea. As many traits of quantitative inheritance are sought after in the breeding process, a recurrent selection scheme is very often recommended due to its potential for breaking up undesirable linkage blocks and for accumulating desirable alleles in a single genotype. Such schemes initially require the buildup of sufficiently large populations from repeated selection and intermating between the selected parents. Mutation breeding may be used to create new variability for the characters showing a positive effect on pod borer resistance. Breeding for resistance to insect-pests results in a net return of $\$ 300$ per $\$ 1$ of investment in research (Dua et al. 2005).

The breeding approach to pod borer resistance in chickpea is an integrated one involving both the antixenosis/antibiosis and avoidance mechanisms (Clement et al. 1992). Given that malate-mediated resistance is most likely to be quantitatively inherited and that sources significantly superior to ICC 506 have yet to be identified, the best prospect for increasing resistance using antixenosis and antibiosis is through recurrent selection. The antixenosis/antibiosis approach can be complemented by the avoidance approach (i.e., selecting genotypes with the capacity to set seed under low-temperature regimes or early-maturing genotypes). Large genetic variation for these phenological traits has been reported, and the breeder can make use of it to avoid the damage caused by the pod borer in chickpea. Therefore, the breeding goal should be to identify, characterize, and utilize the genetic mechanism that confers durable resistance to pod borer (Dua et al. 2002). The mechanisms for resistance are presented in Table 1.

Parents ICC 506, ICC 10619, and ICCL 84205 with low borer damage were found to be useful in the breeding programs for pod borer resistance (Singh et al. 1991). Pedigree selection was effective in differentiating low vs. high borer damage. Progenies of plants selected as low borer $(15.1 \%)$ showed significantly greater tolerance (less susceptible) compared to those selected as high borer (16.1\%). Correlation between pod borer damage in $\mathrm{F}_{2}$ and $\mathrm{F}_{3}$ progenies was low, but positive $(0.26, p<0.01)$ (ICRISAT 1981). Pedigree selection for low borer damage under pesticide-free conditions was found effective in identifying borer-resistant lines. Singh et al. (1997) developed ICCV 7 from a cross between H208 and BEG 482 and registered it as resistant to pod borer. Some of the varieties released, such as Vishal and Vijay, showed higher resistance to pod borer damage (Deshmukh et al. 1996a, 1996b). The screening of wild relatives of $C$. arietinum showed that the incidence of Helicoverpa larvae on C. echinospermum, C. judaicum, C. pinnatifidum, and C. reticulatum was significantly less than the cultivated species (Kaur et al. 1999).

Considering that the resistance to pod borer is polygenic and the loci may vary in different segments on different resistance sources, efforts were made to pyramid genes from several resistant sources. Eight resistant parents were involved in a multiple cross (four single crosses and two double crosses, leading to one eight-way cross) at ICRISAT. The $\mathrm{F}_{2}$ of the multiple crosses was screened in non-sprayed field conditions to select resistant plants. From these, $300 \mathrm{~F}_{3}-\mathrm{F}_{5}$ progenies were evaluated in an unsprayed field in 1994-95, and $42 \mathrm{~F}_{5}$ lines were selected for further evaluation. The best $\mathrm{F}_{5}$ progeny (ICCV 95992) showed less than $1 \%$ damage compared to $7 \%$ damage in the resistant control ICC 506. In the yield test (under unsprayed and rain-fed conditions), ICCV 95992 suffered 8\% damage and produced a seed yield of $0.93 \mathrm{t} \mathrm{ha}^{-1}$. The resistant control (ICC 506) showed $8.5 \%$ damage and yielded $0.65 \mathrm{t} \mathrm{ha}^{-1}$ (ICRISAT 1996). Although complete resistance is not available, ICC 506 has shown consistently lower pod damage over the years and improved yields under unsprayed conditions (Gowda et al. 1983). However, most of the pod borer-resistant lines are highly susceptible to wilt caused by Fusarium oxysporum f. sp. ciceri. The problem of the linkage between pod borer resistance and susceptibility to fusarium wilt has been overcome with the identification of the lines ICCL 86102, ICCL 86111, ICPX 730020-1-1-1H, IPC 94-93, IPC 94-94, and IPC 94-102 (Singh et al. 1990; Rheenen and Van Rheenen 1991; Chaturvedi et al. 1998), which combine resistance to both wilt and pod borer.

Several studies have been conducted by many scientists on screening chickpea genotypes for resistance and tolerance to pod borer (Borikar et al. 1982; Dias et al. 1983; Tripathi and Sharma 1984; Whightman et al. 1995; Hafeez and Kotwal 1996; Patnaik and Mohapatra 1997; Rashid et al. 2003; Shafique et al. 2009; Nadeem et al. 2011; Sarwar 2013; Mansour and Mohamed 2014; Choudhary et al. 2015). In ICRISAT, India, more than 14,000 chickpea germplasm accessions have been screened for resistance to pod borer under 
Table 1 Characters with different resistance mechanisms in chickpea

\begin{tabular}{ll}
\hline Mechanism & Character(s) \\
\hline $\begin{array}{l}\text { Antixenosis } \\
\text { (non-preference) }\end{array}$ & $\begin{array}{c}\text { Pod shape, pod wall thickness, foliage color, } \\
\text { glabrousness, trichomes } \\
\text { Antibiosis }\end{array}$ \\
$\begin{array}{l}\text { Malic acid content, crude fiber, non-reducing } \\
\text { sugars, low starch, cellulose, hemicelluloses, } \\
\text { lignin in the pod wall, trypsin inhibitors, and HG } \\
\text { proteinase inhibitors }\end{array}$ \\
Avoidance (escape) & Earliness with cold tolerance \\
\hline
\end{tabular}

field conditions. Several germplasm accessions (ICC 506EB, ICC 10667, ICC 10619, ICC 4935, ICC 10243, ICCV 95992, and ICC 10817) with resistance to pod borer have been identified (Lateef 1985; Sharma 2005), and varieties such as ICCV 7, ICCV 10, and ICCL 86103, with moderate levels of resistance, have been released for cultivation (Sharma 2005). However, most of these lines are highly susceptible to Fusarium wilt. Therefore, concerted efforts have been made to break the linkage by raising a large population of crosses between the pod borer-resistant lines and the wilt-resistant lines. Inheritance of resistance to damage by pod borer is largely governed by the additive gene action, while dominance genetic variation is predominant in governing the inheritance of the antibiosis component of resistance (larval survival and larval weight) and grain yield. Further studies on mechanisms and inheritance of resistance and use of morphological, biochemical, and molecular markers will be useful for increasing the levels and diversifying the basis of resistance to pod borer in chickpea (Sharma et al. 2008). Similarly, many workers tested various chickpea cultivars/advanced breeding lines and identified the resistance/tolerance sources against pod borer (Table 2).

In India, Rajput et al. (2003) evaluated eight chickpea genotypes against pod borer and observed that its larval population ranged from 1 to 50 larvae per plant, with pod damage from 8 to $90 \%$ and grain yield from 23 to $1920 \mathrm{~g}$ per plot. The genotype C-727 was found to be relatively resistant against chickpea pod borer among the eight tested genotypes. Shafique et al. (2009) screened 13 advanced lines of kabuli chickpea and reported that pod damage ranged from 13.3 to $22.7 \%$ on the most and least susceptible lines, respectively. The kabuli chickpea genotype $\mathrm{CH} 73 / 02$ was a highly resistant genotype showing the lowest pod damage (8.2\%). Genotypes $\mathrm{CH} 72 / 02$, $\mathrm{CH} 77 / 02$, and $\mathrm{CH} 80 / 02$ showed moderate resistance and $\mathrm{CH} 79 / 02, \mathrm{~B}$ 17/03, $\mathrm{CH}$ 65/02, and $\mathrm{CH}$ 60/02 showed the least resistance in Faisalabad, Pakistan (Nadeem et al. 2011). In Sudan, genotypes Atmore and Flip03-139c recorded a higher level of resistance against pod borer than the Mattama, Hawata, Selwa, Wad Hamed, Jebel Marra, Flip03-127c, and Flip04-9c genotypes, which showed moderately resistant to pod borer (Mansour and Mohamed 2014).

\subsection{Agronomic manipulations (cultural practices)}

\subsubsection{Sowing time}

Sowing chickpea at the optimum time is one of the most important factors affecting crop yield. Weather factors, such as maximum and minimum temperatures, sunshine hours, and wind speed, are important in regulating the pod borer population. It was reported that the pod borer larval population is positively correlated with temperature, whereas relative humidity and rainfall inhibit the larval population (Kumar and Bisht 2013; Shinde et al. 2013). The crop sown later suffered most from the pod borer infestation, as compared with that which was sown earlier. Early sowing of chickpea resulted in low pod borer larval population and pod damage percentage in Pakistani (Akhtar et al. 2014) and Indian conditions (Garg 1990; Choudhary et al. 2015; Parmar et al. 2015). The grain yield was also decreased as sowing was delayed, indicating a direct correlation with pest incidence (Borah 1998; Singh et al. 2002). In general, the pod borer larvae population was less in the crops sown in October in comparison to the crops sown in November under Indian conditions (Anonymous 2013). In northern India, larval peaks of Helicoverpa occur during 10 16 standard weeks and, hence, early sowing or use of short duration chickpea cultivars should permit crop maturity before peak pest load. Late-sown chickpeas can also provide a host for the next generation of Helicoverpa and allow a continuous buildup of resistance (Cumming and Jenkins 2011). In the hilly regions with prolonged crop duration, low infestation of the pest in early-sown crops can be attributed to the fact that the Helicoverpa moths generally emerge from diapausing pupae in late March or early April, when the weather starts warming up. The egg laying and development of early instar larvae take place during the 2 nd and 3rd weeks of April. The early instars generally remain confined strictly to leaves, while the later instars, which usually cause substantial damage, emerge towards the 3rd to 4th weeks of April. By that time, the pods on the early-sown crops are almost fully developed and very little damage can be inflicted on them. Thus, the early-sown crops escape the period when the later instar larvae infest the pods, whereas the late-sown crops suffer considerably.

In contrast, in Bangladesh the pod borer population was higher in the early-sown crops (October 15 to November 1) and in those with delayed sowing dates from November 1 to 30 , where the pest population decreased and then increased again. It was observed that both the early (October 15 to November 1) and late-sown (December and onward) crops received higher pod borer damage and produced lower yield. However, the mid-sown (November 8 to 30) crops received less pod borer damage and produced higher yield. Hence, to ensure higher yield with less pod borer damage, chickpea should be sown within the range of November 8 to 30 , and 
Table 2 Sources of resistance to pod borer, Helicoverpa armigera H., in chickpea

\begin{tabular}{|c|c|c|}
\hline Location/country & Tolerant genotype(s) & Reference \\
\hline Myanmar & ICCX 730008-8-1-IP-BP and ICC 506 & Ahmed et al. (1990) \\
\hline Nepal & $\begin{array}{l}\text { ICCX 860043-BP, ICCX 900239-BP, ICCV } \\
\text { 95991, ICCV 88102, and GLK 88341 }\end{array}$ & Thakur (1998) \\
\hline \multirow[t]{10}{*}{ India } & Chaffa & Bhatt and Patel (2001) \\
\hline & C-727 & Rajput et al. (2003) \\
\hline & ICC 87311 and ICCV 2 & Sanap and Jamadagni (2005) \\
\hline & JG 315, JG 74, BG 256, JG 130, and ICCV 7 & Ahmad and Rai (2005) \\
\hline & IPC 96-3 & Kaur et al. (2005) \\
\hline & ICC 16374 & Patil et al. (2007) \\
\hline & ICC 506 EB, ICC 12478, ICC 12479 & Lakshmi Narayanamma et al. (2007) \\
\hline & BG-372, HC-1, SAKI-9516, Vijay, and Avrodhi & Deshmukh et al. (2010) \\
\hline & Vijay, Vishal, ICCV 10, ICPL 88034, and ICCL 86103 & Sharma et al. (2014) \\
\hline & CSJD-884 and RSG-931 & Choudhary et al. (2015) \\
\hline \multirow[t]{8}{*}{ Pakistan } & C-727 & Akbar et al. (2003); Sarwar et al. (2009) \\
\hline & $\mathrm{Pb}-91$ & Shahzad et al. (2005) \\
\hline & $\mathrm{CM}-72$ & Khan et al. (2009) \\
\hline & CM 188/01, CH 07/02, CH 20/02 and CH 84/02 & Shafique et al. (2009) \\
\hline & B 8/02, B 8/03, CH 4/02, and $\mathrm{CH} 9 / 02$ & Nadeem et al. (2010) \\
\hline & $\mathrm{CH} 73 / 02$ & Nadeem et al. (2011) \\
\hline & CM-24-2/02, CM-210/01, CH-53/99, and CC-94/99 & Sarwar (2013) \\
\hline & $\mathrm{K}-70005$ & Shabbir et al. (2014) \\
\hline Bangladesh & $\begin{array}{l}\text { ICCV-98939, ICCV-95138, ICCV-96020, ICCV-97004, } \\
\text { BCX-91042-3, and BCX-91040-3 }\end{array}$ & Hossain (2009) \\
\hline \multirow[t]{2}{*}{ Kenya } & $\begin{array}{l}\text { ICC } 2580, \text { ICC 7272, ICCV 92311, ICC 3362, ICCV 95311, } \\
\text { ICC 506, EC 583311, and ICCVX 906183-1 }\end{array}$ & Mulwa et al. (2010) \\
\hline & $\begin{array}{l}\text { EC58318, ICCV10, ICC14831, EC583260, EC583264, } \\
\text { and EC583250 }\end{array}$ & Ruttoh et al. (2013) \\
\hline Sudan & Atmore and Flip03-139c & Mansour and Mohamed (2014) \\
\hline
\end{tabular}

the best sowing date seems to be November 15 (Hossain et al. 2008b).

\subsubsection{Plant density/planting geometry}

Plant density also affects the extent of damage caused by pod borer. In general, a denser plant population favors increased pod damage (Reed et al. 1987; Naresh et al. 1989; Qadeer and Singh 1989; Begum et al. 1992). However, higher plant densities may not necessarily result in yield loss due to compensation in the total pod number per unit area (Sithanantham and Reed 1979; Pimbert 1990). In any case, farmers have a limited ability to manipulate plant population due to such factors as unreliable seed viability, seedling diseases, and adverse physical soil conditions at crop establishment. Higher plant density and planting geometry likely favor pest growth by creating a micro-climate conducive to their dark-loving Helicoverpa larvae. Population dynamics of Helicoverpa on chickpea revealed that higher population of larvae and pupae and higher-density crops harbored more population than low- plant density crops (Sithanantham et al. 1981; Kant et al. 2007).

Increasing the seed rate results in closer planting geometry which supports a higher Helicoverpa larval population. Increasing the seed rate from 75 to $100 \mathrm{~kg} \mathrm{ha}^{-1}$ greatly increased the percentage of pod damage. Further, increasing the seed rate from 100 to $125 \mathrm{~kg} \mathrm{ha}^{-1}$ did not show a significant increase in pod damage. But the increased pod damage in higher seed rate did not affect chickpea grain yield due to the higher plant population per unit area, which compensated for the increased pod damage (Anilkumar et al. 2011).

\subsubsection{Nutrient management}

Fertilizers are primarily applied to produce high yield of a crop, but their use may have an indirect effect on pest attacks. This effect may be positive or negative (Coaker 1987). The higher level of NPK application results in vigorous plant growth that makes the plants bushy, rendering them more susceptible to pod borer. The bushy nature of the plant 
provides better shelter to dark-loving pod borer, causing increased pod damage (Hossain et al. 2009). Low to moderate doses of NPK fertilizer led chickpea to have lower pod borer infestation, but higher doses of NPK led to higher pod borer infestation (Hossain et al. 2009). The reason for this is not clear. However, it could be stated that such a reduction in pod borer damage might be due to a complex mechanism occurring in the plant system that builds up anatomical features of pods in such a way that it may develop resistance power against the damaging pod borer activity. Increased phosphorous levels drastically reduced the pod borer incidence and increased the chickpea seed yield (Anilkumar et al. 2011). Coaker (1987) cited that the use of fertilizers can also change the physiology of the plant making it more "active" as a host for an insect-pest. Applying organic manures like farm yard manure, neem cake, and vermicompost resulted in the lowest pest population compared to the application of inorganic fertilizers (Rao 2003; Muddukumar 2007; Singh and Singh 2007). Rhizobium inoculation did not have a significant overall effect, but nitrogen application led to a significant increase in pod borer damage (Ramakrishnan et al. 1983).

\subsubsection{Inter/mixed cropping systems}

Intercropping in the traditional farming system provides insurance against pest and aberrant weather, in addition to its other advantages over sole cropping. It offers an excellent opportunity for ecological maneuvering of the faunal population by bringing about changes in crop geometry and the cropping system, which may have a relevant economic impact on pest damage.

Intercropping chickpea with certain crops has been shown to reduce damage from pod borer. This may be a result of the companion crop harboring higher numbers of natural enemies or non-preference for egg laying by pod borer in a field containing the intercrop. By concealing a plant among other species, which do not offer the same kind of stimuli, it should be possible to reduce the efficiency of the pest's host seeking behavior and to interfere with its population development and survival (Pimbert 1990).

Intercropping chickpea with linseed, wheat, and mustard, as well as other non-host crops, has been reported to significantly lower the pod damage compared to chickpea sole crops (Lal et al. 1985b; Yadava 1987; Ahmad 2003). Similarly, pod borer damage was reduced by $38.3 \%$ in chickpea + wheat mixed cropping as compared to chickpea sole cropping (Ali et al. 1998). Intercropping generally delayed the appearance of major chickpea pests and reduced their incidence, particularly the linseed intercrop (Mehto et al. 1988; Mehta et al. 1989; Prasad and Kumar 2002; Lal et al. 2002; Borah et al. 2010). According to Tripathi et al. (2008), the minimum larval population and the highest chickpea grain yield were found in chickpea + mustard, followed by chickpea + barley and chickpea + wheat. Similar results have also been supported by Prasad and Chand (1989), Hossain (2003), and Reena et al. (2009).

Coriander and other nectar-rich plants encourage parasitoid activity. Chickpea intercropped with coriander harbored the minimum Helicoverpa population and reduced the incidence of pod borer (Sekar et al. 1996; Nath and Chakravorty 2005; Pandey and Ujagir 2008; Singh and Pandey 2014; Chandra et al. 2014). It has been observed that the older larvae were preferred by Campoletis illota and the younger ones were attacked more by $C$. chloridae. The parasitization of the older larvae by C. illota ranged from 7.0 to $12.5 \%$ (Nath and Rai 1999). Safflower and sunflower intercropped with chickpea reduced pod damage due to the distribution of larvae among chickpea and intercrop during chickpea pod development stages and also due to the conservation and enhancement of natural enemies in intercropping (Sidde Gowda et al. 2004; Pattar et al. 2012).

\subsubsection{Trap crops}

Trap crops are grown as a control measure to lure pests away from the cash crop to protect it from attacks. Pests are either prevented from reaching the crop or concentrated in certain parts of the field away from the main crop. The principle of trap cropping relies on pest preference for certain plant species, cultivars, or a certain stage of crop development. Plants produce chemicals, or volatiles, that attract insects for pollination and repel insect-pests. Different species and cultivars produce varying degrees of unique volatiles, allowing certain species or varieties to repel insect-pests more strongly than others, making them suitable as a trap crop. The two primary techniques utilized in trap cropping are (1) selection of a more preferred plant species or cultivar grown at the same time as the main crop and (2) planting the same species and cultivar as the main crop, timed to be at the most preferred stage of development before the main crop. Whether using the same or a different species, it is essential that the trap crop be more attractive than the main crop.

Trap cropping offers several benefits in a pest management system. When trap crops successfully attract pest populations, damage to the main crops is limited; therefore, main crops seldom require treatment with insecticides. When insectpests are highly concentrated in trap crops, they can be treated in a localized area instead of treating the entire field. Savings resulting from reduced pest attack and insecticide use may substantially outweigh the cost of maintaining crops that do not provide economic income. Reduced damage to main crops also increases their expected marketable yield. Further, a variety of plantings and increased concentration of insect-pests may attract natural enemies, enhancing naturally occurring biocontrol. 
The trap crop is planted to attract pod borer emerging from diapause. The trap crops are destroyed before larvae commence pupation. As a result, the overall pod borer pressure on crops is reduced, resulting in greater opportunity for adopting soft control options, reduced insecticide use, and greater activity of the natural enemies. The trap crops used either marigold or sunflower and were raised in different ratios and border rows. The pod damage percentage was low when the trap crops were grown in a ratio of 5:1 to 7:1. Trap crops along border rows, alone, recorded 11.24 and $34.05 \%$ pod damage in marigold and sunflower trap crops, respectively (Anonymous 2009).

\subsubsection{Bird perches}

Several species of insectivorous birds have been found to feed on crop insect-pests, including pod borer (Chakravarthy 1988), which have been known to reduce the larval population to the extent of $84 \%$ in Punjab, India. Among the predatory birds, black drongo, house sparrows, blue jays, cattle egret, rosy pastor, and mynah are common predators on a large number of $H$. armigera and lepidopteran insects of chickpea, pigeon pea, and groundnut crops (Gokhale and Ameta 1991). Though the world is bestowed with a rich heritage of avian diversity (Ali and Dillon 1983), the beneficial role of insectivorous birds in insect-pest management has not received much recognition beyond faunistic documentation. This is mainly due to the over-dominance of broad-spectrum insecticides in the plant protection scenario (Gopali 1998; Gopali et al. 2007, 2008). Therefore, the development and implementation of eco-friendly management of the chickpea pod borer is of paramount importance in achieving sustainable production.

The sunflower acted as the most suitable live bird perch in the chickpea ecosystem, as it is a very fast-growing plant and provided rigid support for alighting insectivorous birds right from the vegetative stage until crop maturity. Major predatory birds alighted on the sunflower perch, reducing the larval number within the shortest time. Predatory wasps carrying a large number of larvae were recorded on sunflower plants. The results of a field study revealed that sowing sunflower ( $50 \mathrm{~g}$ seeds $\mathrm{ha}^{-1}$ ) and sorghum ( $50 \mathrm{~g} \mathrm{seeds} \mathrm{ha}^{-1}$ ) along with chickpea seeds recorded lower larval numbers over the absence of live bird perches (Gopali et al. 2009). The number of coccinellids was higher on sunflower plants. Similarly, the tachinid fly population was the highest, accounting for 75 to $90 \%$ of the parasitization of late instar larvae. The study concluded that sowing sunflower $\left(50 \mathrm{~g} \mathrm{ha}^{-1}\right)$ and sorghum ( $50 \mathrm{~g} \mathrm{ha}^{-1}$ ) along with chickpea seeds recorded higher chickpea grain yield with the highest net returns over Profenophos $50 \mathrm{EC}$ at $3.0 \mathrm{ml} \mathrm{l}^{-1}$ (1:5.12) as a standard check. The importance of intercropping sunflower with chickpea in reducing the incidence of pod borer damage was also confirmed by Pattar et al. (2012).

\subsection{Monitoring Helicoverpa through pheromone traps}

Regularly monitoring the key pest is a vital component of any Integrated Pest Management (IPM) program that helps to take control measures. An effective control strategy always depends on accurate monitoring of damaging stages of the insect. Monitoring or recording is also necessary to understand the major factors influencing pest population to forecast its incidence. Pheromone traps can be incorporated to develop predictive models designed to provide information on probable oviposition patterns, and population abundance of pod borer moth catch is positively correlated with the larval count (Prabhakar et al. 1998). Hossain (2008) reported results on the emergence, promptness, and seasonal fluctuation of pod borer moths for adopting effective pest management technology at Pulses Research Center in Ishurdi, Bangladesh. The results inferred that moth catching was increased gradually and reached its peak in the month of April, then gradually decreased and diminished to zero in the last week of July, and ultimately remained at zero until December. IPM against chickpea pod borer should be initiated from mid-January to manage its population effectively. In Nepal, Prasad and Newpane (1992) reported the maximum amount of moth trapping during the last week of February and the first week of April. The pheromone trap catches were negligible from the 45 th to 50th weeks, and again from the 1st to 10th standard weeks in March, trap catches were nil, though the larval population was noticed during pre-winter months. From the 11th standard week, moth catches/traps started increasing and it reached its peak during the 15 th to 16 th standard week in April. It further decreased until the 19th to 20th standard weeks in May, when the crop was harvested. An increase in pest population during the post-winter months between the 9th and 15th standard weeks has been reported to be a regular trend in northern India (Ahmad 2003). Higher moth catches as well as increased larval population in fields have been observed during April to May (Reena et al. 2009). Yadava et al. (1991) observed pod borer larvae, occurring at all growth stages of the crop, as being less than 0.81 larvae per square meter at the foliage stage and more than 19.02 larvae per square meter at the podding stage.

\subsection{Biological control}

Biological agents offer an alternative to chemicals for economically viable and ecologically sustainable management of chickpea pod borer. Biological control is a bioeffector method of controlling pests using other living organisms such as plants, animals, bacteria, and virus-based products. It relies on predation, parasitism, herbivory, or other natural 
mechanisms, but typically also involves an active human management role.

\subsubsection{Plant and animal-based extracts}

Plant materials are known by farmers to be environmentally benign, safer, and more cost-effective compared to synthetic pesticides (Kamanula et al. 2011), as well as difficult to adulterate when produced or harvested by farmers themselves. The most well-known and commonly used plant extract is azadirachtin, isolated from the seed, wood, bark, leaves, and fruits of the neem tree (Azadirachta indica). Azadirachtin has both antifeedent and growth-retarding properties and can lead to death at any stage in the life cycle, probably by interfering with the neuroendocrine control of metamorphosis in insects (Roy and Dureja 1998). Neem and garlic extract have larvicidal, toxic, repellent, ovicidal, antifeedent and antioviposition effects on insect-pests (Cavallito and Balley 1944; Amonkar and Banerji 1971; Zhu et al. 2001). Applying Neem Seed Kernel Extract (NSKE 5\%) treatment reduced the pod borer population in chickpea (Gupta 2007; Pachundkar et al. 2013; Hussain et al. 2016). Leaf, bark, and seed extract from Annona squamosa have pesticidal and insect antifeedent properties (McLaughlin et al. 1997; Alali et al. 1999; Bisen and Bansal 2014). Applying a potent plant pesticide with vermiwash is the best alternative to chemical fertilizer and pesticides (Ma et al. 2000). In India, Mishra et al. (2013) reported a significant decrease in the percentage of pod damage after spraying vermiwash with neem oil and custard apple leaf extract. The vermiwash, combining animal dung and municipal solid wastes with aqueous garlic extract, caused the maximum percentage of reduction in the pod borer infestation rate. The vermiwash obtained from buffalo dung and municipal solid wastes with neem oil and garlic extract were more effective for better plant growth, productivity, and management of the pod borer infestation rate. Integrated application of plant- and animal-based products like pongamia leaf extract $(10 \%)+$ $\operatorname{NSKE}(10 \%)+$ aloe $(0.5 \%)+$ cow urine $(30 \%)$, GCA $(2 \%)+\operatorname{GCK}(0.5 \%)$, and vitex leaf extract $(20 \%)+$ clerodendron extract $(4 \%)+$ cow urine $(17 \%)$ reduced the maximum larval population with a higher chickpea pod yield (Ladji et al. 2011; Mallapur and Ladji 2010).

\subsubsection{Bacteria-based insecticides}

Microbial insecticides can be used for managing pod borer populations, and their use would reduce reliance on toxic chemicals released into the agro-ecosystem, e.g., soil toxicity, phytotoxicity, air pollution, and toxicity to mammals and birds. In the developed world, use of Bacillus thuringiensis (Bt)-based microbial insecticide preparations provides an eco-friendly alternative to the generally hazardous broad-spectrum chemical insecticides (Ahmed et al. 2012). The efficacy of Bt can be enhanced by incorporating suitable quantities of acids, salts, oils, adjuvants, thuringiensin (exotoxin of Bt), and chemical insecticides (Salama 1984; Salama et al. 1986; Karel and Schoonhoven 1986; Morris 1988; Ahmed et al. 1989; Ahmed et al. 1990; Khalique and Ahmed 2001, 2003). Applying DiPel 2X and DiPel ES at 1.6 and $1.51 \mathrm{ha}^{-1}$, respectively, at early stages of crop infestation (1st, 2nd, and 3rd instar larval infestation) with at least two applications at 7-day intervals resulted in increased chickpea yield (Ahmed et al. 1994; Ahmed 1999; Ahmed and Khalique 2012). Preparations of Bt-based insecticides, with BioBit, Delfin, and DiPel together with NPV showed minimum pod damage (Anonymous 1997). It appears that $B t$-based insecticides can act as effective IPM tools if an awareness is developed among farmers about the critical time and method for their safe application.

\subsubsection{Virus-based insecticides}

Most natural pod borer populations have at least some degree of infection by species-specific nuclear polyhedrosis viruses (NPVs). If the degree of NPV infection can be enhanced, the larval population can be decimated without deleterious effects on any other organisms. In India, extensive studies evaluating NPVs have resulted in the development of technologies for successful application of indigenous NPV preparations to combat pod borer in chickpea. Thakur (1998) applied an NPV preparation at $1.5 \mathrm{ml} \mathrm{l}^{-1}$ and obtained higher grain yield, not significantly different from that with a chemical insecticide (Deltamethrin 2.8 EC applied at $1.0 \mathrm{ml} \mathrm{l}^{-1}$ ), but significantly more than an unsprayed control. Sharma et al. (1997) reported high pod borer larval mortality in bioagent and chemical insecticide treatments. NPV at $300 \mathrm{LE} \mathrm{ha}^{-1}$ caused a $78.7 \%$ reduction in larval population, resulting in $10 \%$ pod damage and high grain yield $\left(1.86 \mathrm{t} \mathrm{ha}^{-1}\right)$, whereas the chemical insecticide Endosulfan $35 \mathrm{EC}$ at $1200 \mathrm{ml} \mathrm{ha}^{-1}$ caused a $70.9 \%$ reduction in larval population, resulting in $11.2 \%$ pod damage and $1.86 \mathrm{t} \mathrm{ha}^{-1}$ grain yield. Many other workers have reported significant reductions in pod borer larval population and, accordingly, less pod damage in chickpea from NPV application, as compared to chemical insecticides and control measures (Narayana 1980; Anonymous 1982, 1983; Chandra 1987; Jayaraj et al. 1987; Pawar et al. 1987; Rabindra and Jayaraj 1988; Balasubramaniam et al. 1989; Vyas and Lakhohaura 1996; Satish et al. 1998; Pokharkar et al. 1999; Hossain et al. 2001; Hossain 2007). An integrated application of NSKE + HaNPV + Panchagavya has resulted in lower pod damage and produced higher chickpea yield (Muddukumar 2007). This might be due to the ovicidal action of NSKE concentration of azadirachtin content leading to egg mortality. 


\subsection{Integrated management practices}

Current sensitivities regarding environmental pollution, human health, and pest resurgence are a consequence of the improper use of synthetic pesticides. Host-plant resistance, natural plant products, bio-pesticides, natural enemies, and agronomic practices offer a potentially viable option for integrated pest management (IPM). They are relatively safe for non-target organisms and human beings. The IPM module comprised resistant varieties, good agronomic practices, pheromone traps, NSKE, HaNPV, etc., and offers an environmentally friendly alternative for effective management of pod borer in chickpea. The most effective IPM module composed of pheromone trapping + sequential release of the bio-control agent (Trichogramma chilonis + Bracon hebetor) + spraying neem seed kernel extract resulted in the best performance for controlling pod borer, followed by pheromone trapping + sequential release of the bio-control agent (T. chilonis + $B$. hebetor) (Anonymous 2008). The IPM module consisting of sowing chickpea on November 15 and first spraying with HaNPV at $500 \mathrm{LE} \mathrm{ha}^{-1}$ at the $100 \%$ plant pod formation stage and second spraying after 7 days with cermethrin at $1 \mathrm{ml} \mathrm{l}^{-1}$ ensures higher yield and return (Hossain et al. 2010). These results are in line with the findings of Suganthy and Kumar (2000) and Vikram et al. (2000), who evaluated different IPM modules composed of insecticides and bio-pesticides. Similarly, Mahmudunnabi et al. (2014) and Anil Kumar et al. (2015) indicated that the IPM package consisting of pheromone traps in addition to the sequential release of bio-control agents and spraying HaNPV revealed the best performance for reducing pod damage and provided the highest yield, by a significant amount. Integrating weeding, hand-picking, and indoxacarb proved to be the most effective in reducing the larval population and pod infestation, and resulted in the maximum grain yield. The larval population of the combined effect of these practices was not significantly different from hand-picking + indoxacarb, weeding + indoxacarb and indoxacarb alone. Hand-picking, in combination with $B t$ and weeding, also controlled the larval population significantly, but was inferior to the above treatments. The release of $T$. chilonis Ishii (Hymenoptera: Trichogrammatidae) did not control pod borer. Based on the cost-benefit ratio, hand-picking is the most costeffective method for controlling pod borer (Wakil et al. 2009).

\section{Conclusion}

Chickpea sustainability can be achieved by integrated management of pod borer that comprises a proper integration of measures or practices such as breeding resistant cultivars, adopting good agronomic practices, habitat management, and biological control. Some cultural practices such as early sowing of a resistant/tolerant variety with optimum planting density and fertilizer levels and inter/trap crops (viz., coriander, mustard, linseed, sunflower, sorghum, and marigold) and installing animated bird perches (i.e., sunflower and sorghum), along with chickpea seeds with T-perches at 2-m predatory zones, are optimum for high chickpea yields with sustainable pod borer management. Any single method of approach to pest control may not be feasible; hence, the best alternative is the IPM approach, which is based on the principles of managing the pest rather than aiming at its complete eradication. In view of this, the present review concluded that the use of IPM options, along with growing resistant varieties, good agronomic practices, biological control, chemical control (if necessary), behavioral approaches, etc., reduce the negative impact of insecticides on the natural enemies that are present in the suitable ecological niche and will protect the ecosystem and the environment from toxicological hazards.

\section{References}

Ahmad R (2003) Insect-pests of chickpea and their management. In: Ali M, Shiv Kumar, Singh NB (eds) Chickpea research in India. Indian Institute of Pulses Research, Kanpur, pp 69-72

Ahmad R, Rai AB (2005) In: Shiv Kumar, Singh M (eds) 25 years of research on Helicoverpa at IIPR. Indian Institute of Pulses Research, Kanpur, p 54

Ahmed K (1984) Research on pulses entomology at National Agricultural Research Center, Islamabad. Proceedings of the group discussion: pulse pests management, 05-10 Dec 1983, ICRISAT Center, India. Patancheru A.P. 502 324, India, pp 28-30

Ahmed K (1999) Population management of chickpea pod borer Helicoverpa armigera (Hubn.) using pheromone trap and Bacillus thuringiensis Berliner. PhD Thesis, Quaid-i-Azam University, Islamabad, Pakistan

Ahmed K, Khalique F (2012) Oviposition and larval development of Helicoverpa armigera (Hüebn.) (Lepidoptera: Noctuidae) in relation with chickpea, Cicer arietinum L. (Fabaceae) crop phenology. Pakistan J Zool 44:1081-1089

Ahmed K, Khalique F, Afzal M, Malik BA (1986) Pulses entomology report. Food legumes improvement programme. Pakistan Agricultural Research Council, National Agricultural Research Center, pp 4-10

Ahmed K, Khalique F, Malik BA (1989) Studies on Helicoverpa (Heliothis) armigera management in Pakistan. Proc 1st Intl Conf Econ Ent 11:153-161

Ahmed K, Lal SS, Morris H, Khalique F, Malik BA (1990) Insect-pest problems and recent approaches to solving them on chickpea in South Asia. In: Proceeding of Second International Workshop on Chickpea Improvement, 4-8 December 1989, ICRISAT, Patancheru, India, pp 165-168

Ahmed K, Khalique F, Malik BA, Riley D (1994) Use of microbial insecticides in Pakistan: special reference to control of chickpea 
pod borer Helicoverpa (Heliothis) armigera (Hubner). Subtrop Pl Sci 46:38-44

Ahmed K, Khalique F, Durrani SA, Pitafi KD (2012) Field evaluation of bio-pesticide for control of chickpea pod borer Helicoverpa armigera, a major pest of chickpea crop. Pakistan J Zool 44(6): $1555-1560$

Akbar AR, Sarwar M, Ahmad N, Siddiqui QH, Taufiq M (2003) Evaluation for resistance in some local and exotic chickpea genotypes against Helicoverpa armigera (Hb). Pakistan J Biol Sci 6(8): $1612-1615$

Akhtar MF, Ahmed I, Nadeem I, Abbas Q, Raza A, Yousaf MJ, Ahmed R, Niaz T (2014) Impact of different dates of sowing on gram pod borer (Helicoverpa armigera) infestation in chickpea crop. World $\mathrm{J}$ Zoo 9(4):270-275. doi:10.5829/idosi.wjz.2014.9.4.86153

Alali FQ, Liu XX, McLaughlin JL (1999) Annonaceous acetogenins: Recent progress. J Nat Prod (Lloydia) 62:504-540. doi:10.1021/ np980406d

Ali S, Dillon RS (1983) A pictorial guide to the birds of the Indian Subcontinent. Bombay Natural History, Oxford, pp 176-188

Ali M, Agarwal SC, Rathore YS, Mishra JP (1998) Agronomic options in the management of Biotic stresses in pulse crops. In: Proceedings of National Symposium on "Management of Biotic and Abiotic Stresses in Pulse Crops"- Kanpur, June 26-28, 1998

Ali A, Choudhury RA, Ahmad Z, Rahman F, Khan FR, Ahmad SK (2009) Some biological characteristics of Helicoverpa armigera on chickpea. Tunn J Plant Prot 4:99-106

Amonkar SV, Banerji A (1971) Isolation and characterization of the larvicidal principle of garlic. Science 174:1343-1344. doi:10.1126/ science.174.4016.1343

Kiran Kumari, Anil Kumar T, Saha TN, Goswami, Singh SN (2015) Biointensive management of Helicoverpa armigera (Hubner) in chickpea. J Eco-friendly Agric 10(1):50-52

Anilkumar R, Nandan B, Sharma JP, Kumar J (2011) Effect of phosphorus and seed rate on growth and productivity of bold seeded Kabuli chickpea in subtropical Kandi areas of Jammu and Kashmir. Plant Archives 10(1):125-129

Anonymous (1982) Investigation on new strains of Bacillus thuringiensis (Bt) affecting lepidopterous crop pests. Final Technical Report, PL480 program of USDA (PG-Pa-317, PK-ARS-146). Department of Microbiology, University of Karachi, pp 67-78

Anonymous (1983) Insect-pests. Annual report. International Crops Research Institute for the Semi-Arid Tropics, Patancheru, pp 126129

Anonymous (1987) Annual Technical Report, Food Legumes Improvement Project in Pakistan. Pakistan Agricultural Research Council (PARC), National Agricultural Research Center, pp 121133

Anonymous (1997) Entomology annual report, All India coordinated research project on improvement of chickpea. Kanpur, India, pp 204-216

Anonymous (2002) Annual report, food legumes improvement programme. Pakistan Agricultural Research Council. National Agricultural Research Center, Islamabad, Pakistan

Anonymous (2008) Annual report 2007-2008, Entomology Division, BARI, Gazipur, Bangladesh

Anonymous (2009) Annual report 2008-09, All India Coordinated Research Project on Chickpea (AICRPC), Directorate of Pulse Research, Kanpur, India

Anonymous (2013) Annual report 2012-13. Indian Institute of Pulses Research (IIPR), Kanpur

Anwar M, Shafique M (1993) Integrated control of gram pod borer, Helicoverpa armigera (Hubner) in Sindh. In: Proceedings of Pakistan Congress of Zoology, pp 215-222

Armes NJ, Jadhav DR, Bond, De Souza KR (1996) A survey of insecticide resistance in Helicoverpa armigera in Indian subcontinent. Bull Ent Res 86:499-514. doi:10.1017/S0007485300039298
Bakr MA, Afzal MA, Hamid A, Haque MM, Aktar MS (2004) Blackgram in Bangladesh. Lentil, Blackgram and Mungbean Development Pilot Project, Pulses Research Centre, BARI, Gazipur

Balasubramaniam S, Arora RS, Pawar AD (1989) Biological control of Heliothis armigera (Hubn.) using Trichogramma pretiosum Riley and nuclear polyhedrosis virus in Sriganganagar district of Rajasthan. Pl Protect Bull 41:1-3

Begum N, Husain M, Chowdhury SI (1992) Effect of sowing date and planting density on pod borer incidence and grain yield of chickpea in Bangladesh. Int Chickpea Newslet 27:19-21

Bell S (2014) The small but mighty chickpea. Phys.org. Retrieved 8 October 2015

Bhatnagar VS (1987) Conservation and encouragement of natural enemies of insect-pests in dryland subsistence farming: problems, progress and prospects in the Sahelian Zone. Int J Trop Insect Sci 8:791795. doi:10.1017/S1742758400022931

Bhatt NJ, Patel RK (2001) Screening of chickpea cultivars for their resistance to gram pod borer Helicoverpa armigera $(\mathrm{Hb})$. Indian $\mathrm{J}$ Ent 63:277-280

Bisen SK, Bansal SK (2014) Feeding deterrent activity of certain plant extracts against Helicoverpa armigera pest of Cicer arietinum. J Chem Biol Physic Sci 4(4):3296-3300

Borah RK (1998) Influence of sowing dates on the infestation of Helicoverpa armigera and grain yield of chickpea (Cicer arietinum) in the hill zone of Assam. Indian J Ent 60(3):416-417

Borah BK, Debnath MC, Sharma KK, Das B (2010) Effect of intercropping on incidence of gram pod borer, Helicoverpa armigera Hubner in chickpea. Insect Environ 15(4):8-9

Borikar PS, Madansure AN, Jambhale ND, Gite ND, Missal MB (1982) Damage caused by Heliothis armigera Hubner (Lepidoptera: Noctuidae). J Ent 44:290-292

CABI (2006) Crop protection compendium, 2006 edition. CAB International Publishing, Wallingford

CABI (2007) Crop Protection Compendium, 2007 Edition. (C) CAB International Publishing, Wallingford

CABI (2013) Crop protection compendium, 2013 edition. CAB International Publishing, Wallingford

Cavallito CJ, Balley JH (1944) Allicin, the antibacterial principle of Allium sativum L. Isolation, physical properties and antibacterial action. J Am Chem Soc 66:1950-1951. doi:10.1021/ja01239a048

Chakravarthy AK (1988) Bird predators of pod borers of field bean (Lablab niger). Trop Pest Mgmt 34:395-398. doi:10.1080/ 09670878809371285

Chandra S (1987) Production technology from all India pulse improvement project in Nepal. Coordination of grain legume research in Asia. Summary proceedings of the Review and Planning Meeting for Asian Regional Research on Grain Legumes (groundnut, chickpea and pigeon pea), 16-18 December 1985 ICRISAT, Patancheru, India, pp 45-49

Chandra BKN, Rai PS (1974) Two new ornamental host plants of Heliothis armigera Hubner in India. Indian J Horti 31(2):198

Chandra S, Rachappa V, Yelshetty S, Sreenivas AG, Biradar SA (2014) Performance of intercrops in reduction of gram pod borer, Helicoverpa armigera (Hubner) incidence on chickpea. J Exp Zoo 17(2):627-630

Chaturvedi SK, Gurha SN, Sewak S, Ahmed R, Dikshit HK, Bahduoria P (1998) Possible combined resistance against Fusarium wilt and pod borer in chickpea (Cicer arietinum L.) Indian J Pulses Res 11:117119

Choudhary OM, Anwala R, Sharma MM (2015) Studies on varietal screening and date of sowing of chickpea [Cicer arietinum (L.)] against Helicoverpa armigera (Hub.) J Eco-friendly Agric 10(1): 58-61

Clement SI. El-Din, Sharaf EIDN, Weigand S, Lateef SS (1992) Screening techniques and sources of resistance to insect-pests of cool season food legumes. (In En.) (Summaries in En.) Program 
and abstracts. $2^{\text {nd }}$ International Food Legume Research Conference, Cairo, Egypt, 12-16 April 1992. Cairo, Egypt. International Food Legume Research Conference, Organizing Committee, pp 22

Coaker TH (1987) Cultural methods. In: Burn AJ, Coaker TH, Jepson PC (eds) The crop in integrated pest management. Academic Press, London, pp 69-88

Cothran RD, Brown JM, Relyea RA (2013) Proximity to agriculture is correlated with pesticide tolerance: evidence for the evolution of amphibian resistance to modern pesticides. Evol Appl 6:832-841. doi:10.1111/eva.12069

Cumming G, Jenkins L (2011) Chickpea: Effective crop establishment, sowing window, row spacing, seeding depth and rate. Northern Pulse Bull 7:6

Das GP (1987) Efficacy of neem oil on the eggs and grub mortality of Callosobruchus chinensis Linn. (Bruchidae: Coleoptera). Trop Grain Legume Bull 34:14-15

David H, Easwaramoorthy (1988) Physical resistance mechanisms in insect plant interactions. In: Ananthakrishnan TN, Raman A (eds) Dynamics of insect plant in and future trends. Oxford \& IBH Publication, New Delhi, pp 45-70

Deshmukh RB, Mhase LB, Aher RP, Bendre NJ, Kolte TB (1996a) Vishal — a bold seeded wilt resistant, high yielding chickpea variety for western Maharashtra, India. Int Chickpea and Pigeon pea Newslet 3:14-15

Deshmukh RB, Mhase LB, Aher RP, Bendre NJ, Kolte TB (1996b) High yielding wilt resistant chickpea cultivar Vijay for central zone of India. Int Chickpea and Pigeon pea Newslet 3:15-17

Deshmukh SG, Sureja BV, Jethva DM, Sonune VR, Joshi DM (2010) Field screening of chickpea germplasms against pod borer, H. armigera. Legume Res 33(2):150-151

Dias CAR, Lal SS, Yadava CP (1983) Differences in susceptibility of certain chickpea cultivars and local collection to Heliothis armigera (Hubner). Indian J Agric Sci 53:842-845

Dua RP, Gowda CLL, Shivkumar SKB, Govil JN, Singh BB, Singh AK, Singh RP, Singh VP, Kranthi S (2002) Breeding for resistance to Helicoverpa - effectiveness and limitations. In: Sharma HC (ed) Helicoverpa armigera - the way ahead. International Crops Research Institute for the Semi-Arid Tropics, Patancheru

Dua RP, CLL G, Shivkumar, Saxena KB, Govil JN, Singh BB, Singh AK, Singh RP, Singh VP, Kranthi S (2005) Breeding for resistance to Heliothis/Helicoverpa: effectiveness and limitations. In: Sharma HC (ed) Heliothis/Helicoverpa management: emerging trends and strategies for future research. Oxford and IBH Publishers, New Delhi, pp 223-242

Elmosa H (1981) FAO/UNEP Near eastern inter-country program for the development and application of integrated pest control in cotton growing, 1980 report, $\mathrm{p} 44$

EPPO (2006) Distribution maps of quarantine pests, Helicoverpa armigera. On-line available at www.eppo.org/QUARANTINE/ insects/Helicoverpa armigera/HELIAR map.htm

FAOSTAT (2015) http://faostat.fao.org/site/567/default.aspx\#ancor. Accessed 4 June 2015

Gahukar RT (2002) Population dynamics of Helicoverpa armigera (Hubner) (Lepidoptera: Noctuidae) on rose flowers in central India. J Ent Res 26(4):265-276

Garg DK (1990) Effect of sowing date on the incidence of Helicoverpa armigera (Hub) and yield of chickpea in Kumaon Hills, India. Int Chickpea Newslet 23:14-15

Gokhale VG, Ameta OP (1991) Predatory behavious of house sparrow, Passer domesticus L. in the population regulation of Heliothis sp. infesting chickpea, Cicer arietinum. Indian J Ent 53:631-634

Gopali JB (1998) Studies on integrated pest management of pigeon pea pod borer, Helicoverpa armigera (Hubner) with special reference to HaNPV and insectivorous birds. PhD Thesis, University of Agricultural Sciences, Dharwad, India
Gopali JB, Yelshetty S, Teggelli R, Mannur DM (2007) Eco-friendly management of pod borer, Helicoverpa armigera (Hubner) by encouraging predatory birds in chickpea ecosystem. In: National Symposium on Legumes for Ecological Sustainability: Emerging Challenges and Opportunities, 3-5 November 2007, Indian Institute of Pulses Research, Kanpur, p 168

Gopali JB, Siddalingesh, Teggelli R, Yelshetty S (2008) Live bird perches - a non-insecticidal approach for the management of chickpea pod borer, Helicoverpa armigera. Paper presented In: First International Conference on Agrochemicals Protecting Crop, Health and Natural Environment, 8-11 January, 2008, IARI, New Delhi, India, p 214

Gopali JB, Teggelli R, Mannur DM, Yelshetty S (2009) Bird perches for sustainable management of pod borer, Helicoverpa armigera (Hubner) in chickpea ecosystem. Karnataka J Agric Sci 22(3-Spl. Issue):541-543

Gowda CLL, Lateef SS, Smithson JB, Reed W (1983) Breeding for resistance to Heliothis armigera in chickpea. In: Proceedings of the National Seminar on Breeding Crop Plants for resistance to pests and diseases, 25-27 May 1983, School of Genetics, Tamil Nadu Agricultural University Coimbatore, Tamil Nadu, India

Gupta MP (2007) Management of gram pod borer, Helicoverpa armigera (Hubner) in chickpea with biorationals. Nat Prod Radiance 16(5): 391-397

Hackett DS, Gatehouse AG (1982) Diapause in Heliothis armigera (Hubner) and H. jletcheri (Hardwick) (Lepidoptera: Noctuidae) in Sudan Gezira. Bull Entomol Res 72:409-422

Hafeez A, Kotwal DR (1996) Screening of chickpea varieties against gram pod borer, Helicoverpa armigera Hubner. Ann Pl Protec Sci 4:171-172

Hariri G (1981) The problems and prospects of Heliothis management in Southwest Asia. In: Proceedings of International Workshop on Heliothis Management. 15-20 November 1981, ICRISAT, India, pp 369-373

Hashmi AA (1994) Insects pest management, taxonomy and identification. Pakistan Agricultural Research Council (PARC), Islamabad, $p$ 1034

Hossain MA (2003) Management of chickpea pod borer, Helicoverpa armigera (Hubner) through intercropping and insecticide spraying. Thai J Agric Sci 36(1):51-56

Hossain MA (2007) Efficacy of some synthetic and biopesticides against pod borer, Helicoverpa armigera (Hubner) in chickpea. Tropical Agric Res Ext 10:74-78. doi:10.4038/tare.v10i0.1874

Hossain MA (2008) Monitoring and evaluation of chickpea pod-borer Helicoverpa armigera (Hubner) (Lepidoptera: Noctuidae) by using pheromone traps. Bangladesh J Sci Ind Res 43(3):419-426. doi:10. 3329/bjsir.v43i3.1159

Hossain MA (2009) Field screening of chickpea genotypes against pod borer. Bangladesh J Agril Res 34(3):517-521. doi:10.3329/bjar. v34i3.3978

Hossain MA, Rahman MA, Khan ASMR, Rahman MM (2001) Effectiveness of Heliothis nuclear polyhedrosis viruses (HNPV) chickpea pod borer management. Bangladesh J Agric Res 26(4): 625-627

Hossain MA, Haque MA, Prodhana MZH (2008a) Effect of pods characteristics on pod borer, Helicoverpa armigera (Hubner), investigation in chickpea. SAARC J Agric 6(1):1-11

Hossain MA, Haque MA, Prodhan MZH (2008b) Incidence and damage severity of pod borer, Helicoverpa armigera (Hubner) in chickpea (Cicer arietinum L.) Bangladesh J Sci Ind Res 4:221-224. doi:10. 3329/bjsir.v44i2.3676

Hossain MA, Prodhan MZH, Haque MA (2009) Response of NPK fertilizer on incidence of pod borer, Helicoverpa armigera (Hubner) and grain yield of chickpea. Bangladesh J Sci Ind Res 44(1):117124. doi:10.3329/bjsir.v44i1.2720 
Hossain MA, Haque MA, Ahmad M, Prodhan MZH (2010) Development of an integrated management approach for pod borer, Helicoverpa armigera (Hubner) on chickpea. Bangladesh J Agric Res 35(2):201-206. doi:10.3329/bjar.v35i2.5882

Hussain M, Ahmad KS, Majeed M, Mehmood A, Hamid A, Yousaf MM, Chaudhry MS, Shah MJ, Hussain K, Ahmad B, Khan AQ (2016) Integrated management of Helicoverpa armigera on different genotypes of Kabuli chickpea in Punjab, Pakistan. Int J Biosci 9(2):110 119. doi:10.12692/ijb/9.2.110-119

ICRISAT (1981) Chickpea breeding. Annual report 1980-81, ICRISAT, Patancheru 502 324, Andhra Pradesh, India

ICRISAT (1992) Mid-tTerm plan. International Crops Research Institute for Semi-Arid Tropics (ICRISAT), Patancheru

ICRISAT (1996) Annual report, ICRISAT, Patancheru 502 304, Andhra Pradesh, India.

Jayaraj S, Rabindra RJ, Santharam G (1987) Control of Heliothis armigera (Hubn.) on chickpea and lablab bean by nuclear polyhedrosis virus. Indian J Agric Sci 57:738-741

Jeffree E (1986) The cuticle, epicuticular waxes and trichomes of plants, with reference to their structure, functions and evolution. In: BE Juniper and TRE South surface. Edward Arnold Publication Ltd., London, pp 23-64

Kakimoto T, Fujisaki K, Miyatake T (2003) Egg laying preference, larval dispersion, and cannibalism in Helicoverpa armigera (Lepidoptera: Noctuidae). Ann Ent Soc Am 96(6):793-798. doi:10.1603/00138746(2003)096[0793:ELPLDA]2.0.CO;2

Kamanula J, Sileshi GW, Belmain SR, Sola P, Mvumi BM, Nyirenda GKC, Nyirenda SPN, Stevenson PC (2011) Farmers' insect-pest management practices and pesticidal plant use for protection of stored maize and beans in Southern Africa. Int J Pest Mgmt 57(1): 41-49. doi:10.1080/09670874.2010.522264

Kant K, Kanaujia KR, Kanaujia S (2007) Role of plant density and abiotic factors on population dynamics of Helicoverpa armigera (Hübner) in chickpea. Ann Pl Protec Sci 15(2):303-306

Karel AK, Schoonhoven AV (1986) Use of chemical and microbial insecticides against pests of common beans. J Econ Ent 79:16921696. doi:10.1093/jee/79.6.1692

Kaur S, Chhabra KS, Arora BS (1999) Incidence of Helicoverpa armigera (Hubner) on wild and cultivated species of chickpea. Int Chickpea and Pigeon pea Newslet 6:18-19

Kaur H, Gupta SK, Singh D, Singh K (2005) Preliminary evaluation of chickpea genotypes for resistance to pod borer and wilt complex. Int Chickpea Pigeon pea Newslet 12:39-40

Khalique F, Ahmed K (2001) Synergistic interaction between Bacillus thuringiensis (Berliner) and lambda-cyhalothrin (Pyrethroid) against chickpea pod borer, Helicoverpa armigera (Hubner). Pakistan J Biol Sci 4:1120-1123. doi:10.3923/pjbs.2001.1120.1123

Khalique F, Ahmed K (2003) Impact of Bacillus thuringiensis subsp. Kurstaki on biology of Helicoverpa armigera. Pakistan J Biol Sci 6:615-621. doi:10.3923/pjbs.2003.615.621

Khan SM, Inayatullah MY, Khan MA (2009) Varietal screening of chickpea and the efficacy of different insecticides against chickpea pod borer Helicoverpa armigera (HB). Gomal Uni J Res 25(1):20-24

Kumar L, Bisht RS (2013) Population dynamics of Helicoverpa armigera (Hubner) on chickpea crop. Pantnagar J Res 11:35-38

Ladji R, Mallapur CP, Ambika DS, Amitha K, Rudraswamy SM, Thimmegowda PR (2011) Management of chickpea pod borer, Helicoverpa armigera (Hubner) using indigenous materials. Int J Sci Nat 2(2):263-265

Lakshmi Narayanamma V, Sriramulu M, Gowda CLL, Ghaffer MA, Sharma HC (2007) Tolerance to Helicoverpa armigera damage in chickpea genotypes under natural infestation. Indian J P1 Protec 35(2):227-231

Lal SS, Yadava CP, Dias CAR (1985a) Assessment of crop losses in chickpea caused by Heliothis armigera. FAO P1 Prot Bull 33:27-35
Lal SS, Sachan JN, Chandra S (1985b) Cultural and varietal tools for integrated pest management for increasing pulse production. $\mathrm{Pl}$ Protec Bull 37:1-11

Lal OP, Sinha SR, Srivastava YN (2002) Role of intercropping on population buildup of Lipaphis erysimi on cabbage under field conditions. Ann Pl Protec Sci 10:377-378

Lateef SS (1985) Gram pod borer (Heliothis armigera) (Hub.) resistance in chickpea. Agric Ecosyst Environ 14:95-102. doi:10.1016/01678809(85)90087-8

Luckmann WH, Metcalf L (1975) Introduction to insect-pest management. Wiley, New York, pp 3-35

Ma DG, Gordh MP, Zalucki (2000) Biological effects of Azadirachtin on Helicoverpa armigera (Hübner) (Lepidoptera: Noctuidae) fed on cotton and artificial diet. Austr J Ent 39:301-304. doi:10.1046/j. 1440-6055.2000.00180.x

Mahmudunnabi M, Dutta NK, Rahman AKMZ, Alam SN (2014) Development of biorational-based integrated pest management package against pod borer, Helicoverpa armigera Hubner infesting chickpea. J Biopest 6(2):108-111

Mallapur CP, Ladji RN (2010) Management of chickpea pod borer, Helicoverpa armigera (Hubner) using indigenous materials. Int $\mathrm{J}$ Pl Protec 3(2):194-198

Mansour AEA, Mohamed AA (2014) Evaluation of different chickpea genotypes for resistance against pod borer, Helicoverpa armigera (Hub.) (Lepdoptera: Noctuidae) under field conditions, Sudan. Int J Agric Innov Res 2(6):1147-1149

McLaughlin JL, Zeng L, Oberlies NH, Alfonso D, Johnson HA, Cummings B (1997) Annonaceous acetogenins as new natural pesticides: recent progress. In: Hedin PA, Hollingworth RM, Masler EP, Miyamoto J, Thompson DG (eds) Phytochemicals for pest control. ACS Symp 658:117-133

Mehta DN, Singh KM, Singh RN (1989) Influence of intercropping on succession and population buildup of insect-pests in chickpea, Cicer arietinum L. Indian J Ent 50:257-275

Mehto DN, Singh KM, Singh RN (1988) Influence of intercropping on succession and population buildup of insect-pests in chickpea. Indian J Ent 50(3):257-275

Mishra K, Singh K, Tripathi CPM (2013) Management of pod borer (Helicoverpa armigera) infestation and productivity enhancement of gram crop (Cicer aritenium) through vermiwash with biopesticides. World J Agric Sci 9(5):401-408. doi:10.5829/idosi.wjas. 2013.9.5.1749

Morris ON (1988) Comparative toxicity of Delta endotoxin and Thuringiensin of Bacillus thuringiensis and mixture of the two for the Bertha armyworm (Lepidoptera: Noctuidae). J Econ Ent 81: 135-141. doi:10.1093/jee/81.1.135

Muddukumar (2007) Organic nutrient management and plant protection in green chickpea production system. M.Sc. (Agri.) Thesis, University of Agricultural Sciences, Dharwad, India

Multani JS, Sohi AS (2002) Helicoverpa armigera (Hubner) on carnation, Dianthus caryophyllus Linn. in Punjab. Insect Environ 8(2):82

Mulwa RMS, Kimurto PK, Towett BK (2010) Evaluation and selection of drought and pod borer (Helicoverpa armigera) tolerant chickpea genotypes for introduction in semi-arid areas of Kenya. In: Second RUFORUM biennial meeting, 20-24 September 2010, Entebbe, Uganda

Musa AM (2000) On-farm chickpea seed priming trials and demonstrations in the High Barind Tract of Bangladesh. Research Report 1999-2000, People ${ }^{1}$ s Resource Oriented Voluntary Association, Rajshahi, Bangladesh, p 29

Nadeem S, Shafique M, Hamed M, Atta BM, Shah TM (2010) Evaluation of advanced chickpea genotypes for resistance to pod borer, Helicoverpa armigera (Hübner) (Lepidoptera: Noctuidae). Pakistan J Agric Sci 47(2):132-135

Nadeem S, Hamed M, Shafique M, Atta BM, Shah TM (2011) Evaluation for resistance in Kabuli chickpea genotypes against chickpea pod 
borer, Helicoverpa armigera (Hübner) (Lepidoptera: Noctuidae) under field conditions. Songklanakarin J Sci Technol 33(3):291-294

Narayana K (1980) Field evaluation of NPV of Heliothis armigera on chickpea. Proceedings of the workshop on biological control of Heliothis spp., 23-25 September 1980. Department of Primary Industries, Toowoomba, Queensland, Australia

Naresh JS, Malik VS, Kaushik SK (1989) Larval population and damage of Heliothis armigera (Hubn.) estimated on different plant densities of chickpea during five weeks. Bull Ent 27:70-73

Nath P, Chakravorty S (2005) Effect of intercropping on the infestation of chickpea pod borer [Helicoverpa armigera (Hubner)]. J P1 Protec Environ 29(1):86-91

Nath P, Rai R (1999) Study of key mortality factors in the population dynamics of chickpea pod borer, Helicoverpa armigera (Hubner) (Noctuidae: Lepidoptera) infestation chickpea, Cicer arientinum L. Trop Ecol 40(2):281-288

Pachundkar N, Kamble P, Patil P, Gagare P (2013) Management of gram pod borer $H$. armigera in chickpea with neem seed kernel extract as a natural pest management practice in Bhojdari village. Int J Curr Res 5(10):2934-2935

Pande S, Narayana Rao J (2000) Integrated management of chickpea in the rice based cropping systems of Nepal: Progress Report of the ICRISAT and NARC (Nepal Agricultural Research Council, Khumaltar) collaborative work in farmers participatory on-farm trials on the validation of improved production practices [specifically integrated pest (diseases and insects) management (IPM)] in seven villages of five districts in Nepal, $29^{\text {th }}$ October 1999 to $30^{\text {th }}$ April 2000. International Crops Research Institute for the Semi-Arid Tropics (ICRISAT), Patancheru, Andhra Pradesh, India, p 33

Pandey R, Ujagir R (2008) Effect of intercropping on Helicoverpa armigera (Hub.) infesting chickpea. Ann Pl Protec Sci 16(2):320 324

Parmar SK, Thakur AS, Marabi RS (2015) Effect of sowing dates and weather parameters on the incidence of Helicoverpa armigera (Hubner) in chickpea. The Bioscan 10(1):93-96

Patel IS, Patel PS, Patel JK, Acharya S (2010) Pod boring pattern of gram pod borer, Helicoverpa armigera Hub. in chickpea varieties. Insect Environ 16(1):41-42

Patil SK, Shinde GP, Jamadagni BM (2007) Reaction of short-duration chickpea genotypes for resistance to gram pod borer Helicoverpa armigera in Maharashtra, India. SAT eJournal 5(1):1-2

Patnaik HP, Mohapatra R (1997) Performance of chickpea cultivars against Helicoverpa armigera (Hubn) under field conditions in central plateau region of Orissa. Legume Res 18:177-180

Pattar PS, Mansur CP, Alagundagi SC, Karbantanal SS (2012) Effect of intercropping systems on gram pod borer Helicoverpa armigera Hubner and its natural enemies in chickpea. Indian J Ent 74(2): 136-141

Pawar VM, Aleemuddin M, Bhole BB (1987) Bioefficacy of HNPV in comparison with Endosulfan against pod borer on chickpea. Int Chickpea Newslet 16:4-6

Pearson EO (1958) Insect pests of cotton in tropical Africa. Commonwealth Institute of Entomology, London, p 355

Peter AJ, Shanower TG, Romeis J (1995) The role of plant trichomes in insect resistance: a selective review. Phytophaga 7:41-64

Phokela A, Dhingra S, Sinha SN, Mehrotra KN (1990) Pyrethroid resistance in Heliothis armigera $\mathrm{Hb}$. III Development of resistance in field. Pestic Res J 2(1):28-30

Pimbert MP (1990) Some future research directions for Integrated Pest Management in chickpea: a viewpoint. Chickpea in the nineties. In : Proceeding of Second International Workshop on Chickpea Improvement, 4-8 December 1989, ICRISAT, Patancheru, India, pp 151-163

Pokharkar DS, Chaudhary SD, Verma SK (1999) Utilization of nuclear polyhe-drosis virus in the integrated control of fruit borer
(Helicoverpa armigera) on tomato (Lycopersicon esculentum). Indian J Agric Sci 69(3):185-188

Prabhakar M, Singh Y, Newpane SP (1998) Predicting Helicoverpa armigera of chickpea by using sex pheromone traps. Indian J Ent 60(4):339-334

Prasad D, Chand P (1989) Effect of intercropping on the incidence of Helicoverpa armigera (Hub.) and grain yields of chickpea. J Res Birsa Agric Univ 1(1):15-18

Prasad D, Kumar B (2002) Impact of intercropping and Endosulfan on the incidence of gram pod borer infesting chickpea. Indian J Ent 64: 405-410

Prasad LN, Newpane FP (1992) Monitoring the chickpea borer, Helicoverpa armigera (Hubner) over period 1987 to 1990 by pheromone trap at Rampur, Chitwan, Nepal, ACIAR. Food Legume Newslet 17:9

Qadeer GA, Singh YP (1989) Some observations on outbreak of gram pod borer on grain during rabi 1987-88 in Haryana. Pl Protec Bull 41(1-2):24-25

Rabindra RJ, Jayaraj S (1988) Evaluation of certain adjuvants for nuclear polyhedrosis virus (NPV) of Heliothis armigera on chickpea. Indian J Exp Biol 26:60-62

Rahman MM (1990) Infestation and yield loss in chickpea due to pod borer in Bangladesh. Bangladesh J Agric Res 15(2):16-23

Rahman MM, Mannan MA, Islam MA (1982) Pest survey of major summer and winter pulses in Bangladesh. In the Proceedings of the National Workshop on Pulses. Bangladesh Agricultural Research Institute, Joydebpur, Dhaka, pp 265-273

Rajput AA, Sarwar M, Ahmad N, Siddiqui QH, Toufiq M (2003) Evaluation for resistance in some local and exotic chickpea genotypes against Helicoverpa armigera (Hubner). Pakistan J. Biol Sci 6:1612-1615

Ramakrishnan C, Radhakrishnan T, Rama Doss G (1983) Effect of nitrogen, rhizobium inoculation and phosphorus level on damage of pigeon pea by $H$. armigera. Int Pigeon pea Newslet 2:62

Rao KR (2003) Influence of host plant nutrition on the incidence of Spodopter litura and H. armigera on groundnut. India J Ent 65(3): 386-392

Rashid A, Saeed HA, Akhtar LH, Siddiqi SZ, Arshad M (2003) Performance of advance chickpea strains against gram pod borer (Helicoverpa armigera Hubner). Asian J Plant Sci 2:418-419

Reed W (1983) Estimation of crop losses due to insect-pests in pulses. Indian J Ent 2:263-267

Reed W, Pawar CS (1982) Heliothis: a global problem. In: Reed W, Kumble V (eds) Proceedings of International Workshop on Heliothis Management, 15-20 November 1981. ICRISAT, Patancheru, pp 9-14

Reed W, Cardona C, Sithanantham S, Lateef SS (1987) Chickpea insectpests and their control. In: Saxena M, Singh KB (eds) The chickpea. CAB International, Wallingford, pp 283-318

Reena, Singh SK, Sinha BK, Jamwal BS (2009) Management of gram pod borer, Helicoverpa armigera (Hubner) by intercropping and monitoring through pheromone traps in chickpea. Karnataka J Agric Sci 22(3-special issue):524-526

Rheenen HAV, Van Rheenen HA (1991) Chickpea breeding-progress and prospects. Pl Breeding Abst 61:997-1009

Rivnay E (1962) Field crop pest in the near east. Netherlands Junk Publisher, The Hague, p 450

Roy NK, Dureja P (1998) New eco-friendly pesticides for integrated pest management. Pesticides World, New Delhi, pp 16-22

Ruttoh EK, Mulwa RMS, Ngode L, Gohole L, Towett B, Njogu N, Silim S, Rao GVR, Kimurto PK (2013) Screening for host plant resistance to Helicoverpa armigera (Lepidoptera: Noctuidae) in selected chickpea (Cicer arientinum L.) genotypes in Kenya. Egerton J Sci Technol 13:39-55 
Sachan JN, Katti G (1994) Integrated pest management. In: Proceedings of International Symposium on Pulses Research, 2-6 April 1984, IARI, New Delhi, India, pp 23-30

Salama HS (1984) Bacillus thuringiensis Berliner and its role as a biological control agent in Egypt. Z Angew Entomol 98(1-5):206-220. doi:10.1111/j.1439-0418.1984.tb02702.x

Salama HS, Foda MS, Sharaby A (1986) Possible extension of the activity spectrum of Bacillus thuringiensis strains through chemical additives. J Applied Ent 101(1-5):304-313. doi:10.1111/j.1439-0418. 1986.tb00862.x

Saleem M, Younis A (1982) Host plants and nature and extent of damage of Helicoverpa armigera. Pakistan J Agric Res 3:554-558

Sanap MM, Jamadagni BM (2005) Screening of chickpea for resistance to pod borer, Helicoverpa armigera (Hubner) at Rahuri, Maharashtra, India. Int Chickpea Pigeon pea Newslet 12:37-39

Sarwar M (2013) Exploration on resource of resistance in chickpea (Cicer arietinum L.) genotypes to gram pod borer Helicoverpa armigera (Hubner) (Lepidoptera). African J Agric Res 8(26):3431-3435. doi: 10.5897/AJAR11.2452

Sarwar M, Ahmad N, Toufiq M (2009) Host plant resistance relationships in chickpea (Cicer arietinum L.) against gram pod borer (Helicoverpa armigera Hubner). Pakistan J Bot 41(6):3047-3052

Satish K, Malik VS, Kumar S, Dhawan AK (1998) Management pod gram pod borer, Helicoverpa armigera (Hubner) by nuclear polyhedrosis virus in chickpea. Ecological agriculture and sustainable development: Vol. 2. In: Proceedings of International Conference on Ecological Agriculture: Towards Sustainable Development, Chandigarh, India, 15-17 November, 1997, pp 329-333

Saxena HP (1978) Pests of grain legumes and their control in India. In: Singh SR, van Emden HF, Taylor TA (eds) Pest of grain legumes: ecology and control. Academic Press, London, pp 15-23

Sehgal VK, Ujagir R (1990) Effect of synthetic pyrethroids, neem extracts and other insecticides for the control of pod damage by Helicoverpa armigera (Hübner) on chickpea and pod damage yield relationship at Pantnagar in Northern India. Crop Prot 9:29-32. doi: 10.1016/0261-2194(90)90042-6

Sekar PR, Vankataaiah M, Rao NV, Rao VR, Rao VSP (1996) Monitoring of insect resistance in Helicoverpa arimigera (Hub.) from area receiving heavy insecticide application in Andhra Pradesh. J Ent Res 20(2):93-102

Shabbir MZ, Arshad M, Hussain B, Nadeem I, Ali S, Abbasi A, Ali Q (2014) Genotypic response of chickpea (Cicer arietinum L.) for resistance against gram pod borer (Helicoverpa armigera). Adv Life Sci 2(1):23-30

Shafique M, Nadeem S, Hamed M, Atta BM, Shah TM (2009) Performance of some advance desi chickpea genotypes against pod borer, Helicoverpa armigera (Hubner) resistance. Pakistan J Zoo 41:277-280

Shahzad K, Iqbal A, Khalil S, Khattak S (2005) Response of different chickpea (Cicer aritinum) genotypes to the infestation of pod borer (Helicoverpa armigera) with relation to trichomes. Res J Agric Bio Sci 1(1):120-124

Sharma S (1985) Studies on economic threshold and estimation of damage of Heliothis armigera on chickpea. Ph.D. Thesis, Jawaharlal Nehru Krishi Vishwa Vidyalaya, Jabalpur, India

Sharma HC (2005) Heliothis/Helicoverpa management: emerging trends and strategies for future research. Oxford and IBH Publishers, New Delhi

Sharma ML, Rai HS, Verma ML (1997) Biopesticide for management of Helicoverpa armigera (Hubn.) in chickpea. Int Chickpea Pigeon pea Newslet 4:26-27

Sharma HC, Rajeev V, Gaur PM, Gowda CLL (2008) Potential for using morphological, biochemical, and molecular markers for resistance to insect-pests in grain legumes. J Food Legumes 21: $211-217$
Sharma HC, Gaur PM, Srinivasan S, Gowda CLL (2014) Exploiting host plant resistance for pest management in chickpea. Legume Perspectives 3:25-28

Shinde YA, Patel BR, Mulekar VG (2013) Seasonal incidence of gram caterpillar, Helicoverpa armigera (Hub.) in chickpea. Current Biotica 7:79-82

Sidde Gowda DK, Halle D, Sharanabasappa (2004) Evaluation of different IPM modules and intercropping systems for the management of pod borer in chickpea. Karnataka J Agric Sci 17(3):586-589

Singh B, Mandal K (2013) Environmental impact of pesticides belonging to newer chemistry. In: Dhawan AK, Singh B, Brar-Bhullar M, Arora R (eds) Integrated pest management. Scientific Publishers, Jodhpur, pp 152-190

Singh K, Pandey J (2014) Evaluation of intercroppings for management of pod borer, Helicoverpa armigera Hub. in chickpea. Bioinfolet 11(2c):688-691

Singh RN, Singh J (1987) Pattern of boring of chickpea pods by Heliothis armigera Hubn. Indian J Agric Sci 57(5):376-377

Singh BK, Singh RP (2007) Effect of host plant nutrition and pesticidal management on larval population of Helicoverpa armigera (Hubner) in chickpea Cicer arientium. India J Ent 69(4):345-349

Singh KB, Kumar J, Haware MP, Lateef SS (1990) Disease and pest resistance breeding: which way to go in the nineties? In: Proceedings of the Second International Workshop on Chickpea Improvement, 4-8 December 1989. ICRISAT, Patancheru 502 324, Andhra Pradesh, India, pp 233-238

Singh O, Gowda CLL, Sethi SC, Lateef SS (1991) Inheritance of and breeding for resistance to Helicoverpa armigera pod borer in chickpea. In: Golden Jubilee Symposium of Indian Society of Genetics and Plant Breeding, 4-8 February 1991, New Delhi, India

Singh O, Sethi SC, Lateef SS, Gowda CLL (1997) Registration of ICCV 7 chickpea germplasm. Crop Sci 37:295. doi:10.2135/cropsci1997. 0011183X003700010068x

Singh H, Singh I, Mahajan G (2002) Effect of different dates of sowing on the incidence of gram pod borer (Helicoverpa armigera) on different cultivars of chickpea (Cicer arientinum). Agric Sci Digest 22(4): 295-296

Sithanantham S, Reed W (1979) Plant density and pest damage in chickpea. Int Chickpea Newslet 1:9-10

Sithanantham S, Tahhan O, Hariri G, Reed W (1981) The impact of winter sown chickpeas on insect-pest and their management. In: Saxena MC, Singh KB (eds) Proceedings of Workshop on Ascochyta Blight and Winter Sowing of Chickpeas. ICARDA, Aleppo, pp 179-187

Suganthy M, Kumar ST (2000) Integrated pest management strategies against gram pod borer, Helicoverpa armigera (Hubner). Ann Plant Protec Sci 8(2):136-139

Tabashnik BE, Van Rensburg JBJ, Carrière Y (2009) Field-evolved insect resistance to $B t$ crops: definition, theory and data. J Eco Ent 102: 2011-2025

Talhouk AA (1969) Insects and mites injurious to crops in Middle Eastern countries. Verlag Poul Parey, Hamburg, p 239

Thakur P (1998) Helicoverpa management through IPM approach on chickpea and pigeon pea. In: NARC/CLAN, Review and Planning meeting, Nawalpur, Sarlahi, Nepal, 25-27 May 1998, pp 1-10

Tripathi SR, Sharma SK (1984) Extent of damage and incidence of Heliothis armigera (Hubner) (Noctuidae: Lepidoptera) on different varieties of gram in Terai belt of eastern Uttar Pradesh, India. Ann Ent 2:31-35

Tripathi A, Sharma RC, Dwivedi PK, Pandey M (2008) Effect of intercropping and insecticide on pod borer incidence in chickpea. J Food Legumes 21(3):187-188

Ujagir R, Khere BP (1987) Preliminary screening of chickpea genotypes for susceptibility to Heliothis armigera (Hub.) at Pantnagar, India. Int Chickpea Newslet 17:14 
Vikram S, Mathur NM, Kalyan RK, Akhter H, Sharma GK, Singh V, Hussain A (2000) Evaluation of some IPM modules against Helicoverpa armigera (Hubner) on chickpea. Indian J Ent 62(1):24-27

Vyas HG, Lakhohaura BD (1996) Evaluation of Heliothis nuclear polyhedrosis virus for control of Heliothis armigera on chickpea at Pantnagar, (U.P.) Gujarat Agric Uni Res J 21(2):50-54

Wakil W, Ashfaq M, Ghazanfar MU, Afzal M, Riasat T (2009) Integrated management of Helicoverpa armigera in chickpea in rainfed areas of Punjab, Pakistan. Phytoparasitica 37:415-420. doi:10.1007/ s12600-009-0059-y

Whightman JA, Anders MM, Rao VR, Reddy L (1995) Management of Helicoverpa armigera (Lepidoptera: Noctuidae) on chickpea in southern India: Threshold and economics of host plant resistance and insecticide application. Crop Protect 14:37-46. doi:10.1016/ 0261-2194(95)91110-2

White GF (1987) Environmental effects of arid land irrigation in developing countries. MAB Technical Series 8, UNEP/SCOPE/ UNESCO, France, pp 1-67

Yadava CP (1987) Ecological studies on gram pod borer, Heliothis armigera in chickpea in relation to its biotic and abiotic factors. $\mathrm{Ph} . \mathrm{D}$. Thesis, Kanpur University, Kanpur, India

Yadava CP, Lal SS (1997) Studies on host plant resistance against gram pod borer, Helicoverpa armigera in chickpea. In: Symposium on integrated pest management for sustainable crop production, 2-4 December 1997, Indian Agricultural Research Institute, New Delhi, India, p 37

Yadava CP, Sachan JN, Ahmad R, Lal SS (1991) Record of natural enemies of pests of chickpea and pigeon pea. J Biol Control 5:52-54

Yelshetty S (1999) Studies on pigeon pea pod borer, Helicoverpa armigera (Hubner) in pigeon pea ecosystem. Ph.D. Thesis, University Agricultural Sciences, Dharwad, India

Zahid MA, Islam MM, Reza MH, Prodhan MHZ, Rumana Begum M (2008) Determination of economic injury levels of Helicoverpa armigera (Hubner) in chickpea. Bangladesh J Agric Res 33(4):555-563. doi:10.3329/bjar. v33i4.2288

Zalucki MP, Daglish G, Firemponeng S, Twine PH (1986) The biology and ecology of Heliothis armigera (Hübner) and H. punctigera (Wallengren) (Lepidoptera: Noctuidae) in Australia: what do we know? Aust J Zool 42:329-346

Zhu BC, Henderson G, Chen F, Fei H, Laine RA (2001) Evaluation of vetiver oil and seven insect-active essential oils against Formosan subterranean termite. J Chem Ecol 27(8):1617-1625. doi:10.1023/ A:1010410325174 